\title{
Taxonomic, functional and phylogenetic diversity: how subfossil cla- docerans mirror contemporary community for ecosystem functioning: a comparative study in two oxbows
}

\author{
Korponai, János ${ }^{1,2, *}$, Mihály Braun ${ }^{3}$, László Forró ${ }^{4}$, István Gyulai ${ }^{5}$, Csilla Kövér ${ }^{6}$, Judit \\ Nédli ${ }^{4}$, István Urák ${ }^{2}$ and Krisztina Buczkó 7,8 \\ ${ }^{1}$ MTA - PE Limnoecology Research Group, 8200 Veszprém, Wartha Vince u. 1, Hungary. \\ 2 Department of Environmental Sciences, Sapientia Hungarian University of Transylvania, 400193 Cluj-Napoca, \\ Calea Turzii str. 4., Romania. \\ ${ }^{3}$ Isotope Climatology and Environmental Research Centre (ICER), Institute for Nuclear Research, Hungarian \\ Academy of Sciences, 4026 Debrecen, Bem tér 18/C., Hungary. \\ ${ }^{4}$ Department of Zoology, Hungarian Natural History Museum, H-1088 Budapest, Baross u. 13. Hungary. \\ 5 Department of Hydrobiology, University of Debrecen, H-4032. Debrecen, Egyetem tér 1., Hungary. \\ ${ }^{6}$ Food and Wine Research Center, Eszterházy Károly University, H-3300 Eger, Leányka út 6., Hungary. \\ ${ }^{7}$ MTA Centre for Ecological Research, Danube Research Institute, 1113 Budapest, Karolina út. 29, Hungary. \\ 8 Department of Botany, Hungarian Natural History Museum, 1088 Budapest, Könyves Kálmán krt. 40., \\ Hungary. \\ * Corresponding author: korponai.janos@iif.hu
}

Received: 03/05/18

Accepted: 19/10/18

\begin{abstract}
Taxonomic, functional and phylogenetic diversity: how subfossil cladocerans mirror contemporary community for ecosystem functioning: a comparative study in two oxbows

Biases of taxa diversity and traits of source (active) and subfossil cladoceran communities with phylogenetic and functional approach were studied in two oxbows of the River Tisza, Hungary. Subfossil cladoceran communities were found to have suffered species loss due to both the degree of heterogeneity in the lake and taphonomical processes. The remains of heavily chitinized species are those most commonly found in the sediment, and therefore bias communities reconstructed on this basis. These biases are mostly caused by: (1) parts of soft bodied filterers (Daphniidae, Moinidae, Sididae (Diaphanosoma)), which are underrepresented in the subfossil remains of cladocerans, and (2) the remains of species that are difficult to collect and, so, underrepresented or absent in contemporary samples; this may have a strong effect on diversity indices. In spite of such biases, the paleocommunity does reflect the functioning of the ecosystem. The subfossil cladoceran community in the Morotva-tó (MT) corresponded to low fish densities and the high macrophyte coverage, indicating weaker top-down forces in this oxbow. The phylogenetic and functional approach to subfossil cladocerans may be useful in paleolimnological reconstruction, since phylogenetic and trait-based diversity indices correctly predicted top-down regulation as a function of the ecosystem.
\end{abstract}

Key words: active and subfossil Cladocera; oxbow; paleocommunity; trophic status; paleolimnology

\section{RESUMEN}

Sesgos en la diversidad taxonómica, funcional y filogenética de las comunidades vivas y subfósiles de cladóceros

La diversidad de taxones y rasgos de las comunidades de cladóceros actuales (activa) y subfósiles (sedimentada) fueron estudiadas en dos galachos del río Tisza. Hungría. Se investigaron los sesgos entre las poblaciones actuales de cladóceros (comunidad de origen) y la comunidad de cladóceros subfósiles. Estas comunidades subfósiles mostraron una pérdida de especies debido a procesos tafonómicos. Los restos de las especies fuertemente quitinizadas se encuentran más comúnmente 
en el sedimento, produciendo sesgos en las comunidades reconstruidas. Los sesgos son causados principalmente por, (1) las partes de filtradores de cuerpo blando (Daphniidae, Moinidae, Sididae (Diaphanosoma)) que están subrepresentados entre los restos subfósiles de cladóceros, y (2) los restos de especies que son difíciles de recolectar y están subrepresentadas o ausentes en las muestras actuales, y que pueden tener un fuerte efecto sobre los índices de diversidad. A pesar de los sesgos, la paleocomunidad refleja el funcionamiento del ecosistema. La comunidad de cladóceros subfósiles en la laguna MT reflejó una baja densidad de peces, y su alta cobertura de macrófitos indicó el bajo estado trófico de la laguna fluvial. El enfoque funcional en el estudio de cladóceros subfósiles puede ser útil en la reconstrucción paleolimnológica, ya que los indices de diversidad basados en estos rasgos podrían ser mejores indicadores el funcionamiento de los ecosistemas.

Palabras clave: cladóceros subfósiles; galacho; paleocomunidad; estado trófico; paleolimnología

\section{INTRODUCTION}

Multifactor stressors force rapid changes in most ecosystems, and this calls for the intensification of biodiversity studies. Traditionally, biodiversity studies have been based on the number of species within a given ecosystem, and to a lesser extent on the distribution of individuals within a given species in an assemblage (Gaston, 2000; Hamilton, 2005). The majority of studies have focused on common taxonomic indices such as richness and evenness (Hill, 1973). Taxonomic diversity has been used to estimate biodiversity $(\alpha-, \beta$-, and $\gamma$-diversity Whittaker, 1972) and spatial and temporal changes in relation to environmental or anthropogenic factors (e.g. Zhuravlev \& Naimark, 2005; Blarquez et al., 2014). Although this is a well-established approach, it ultimately provides little information on how changes in biodiversity (community composition) affect the functioning of an ecosystem. The correct identification of this is crucial in the case of taxon-based indices, but the biological and ecological role of the species might be of even greater importance in the functioning of an ecosystem (Walker, 1992). At the species- and ecosystem-levels, the identity of species and ecosystem functioning is the result of evolutionary processes and adaptation to given environmental conditions; therefore, the ecosystem functioning may be characterized by the composition of the functional traits of organisms. A functional trait may be defined as a characteristic of an organism relevant to its response to the environment, and thus, to its effects on the ecosystem functioning (Díaz \& Cabido, 2001). Using zooplankton, Thompson et al. (2015) showed that phylogenetic and functional diversity better predicted ecosystem func- tioning than species richness. Phylogenetic diversity (PD) is used as a proxy for functional diversity (FD). The relationship between PD and FD is that evolutionary diversification has generated trait diversification, which may result in greater niche complementarity (Flynn et al., 2011).

Zooplankton occupy a key position in trophic structure and have been used to understand the functioning of aquatic ecosystems (Jeppesen et al., 1997, 2000, 2002, 2011; Iglesias et al., 2011). The taxonomical and functional structure of zooplankton assemblages is influenced by both bottom-up and top-down forces. The nutrient enrichment of lakes fuels the phytoplankton growth, supplying zooplankton with food resources; therefore, at first sight, it seems to increase the biomass of zooplankton. However, to a great extent the relationship depends on the size distribution of the zooplankton. Large zooplankton species such as daphniids are effective filterers, hence their dominance can be expected in zooplankton assemblages in a phytoplankton-rich environment. At the same time, large bodied zooplankters are perfect prey for vertebrate predators; consequently, stocks of them will depend on their various voracious size-selective predators (Confer \& Blades, 1975; Dodson, 1979). In this sense, zooplankton biomass as a function of an ecosystem may be characterized by the composition of zooplankton species that are effective filterers and have a good predator avoidance strategy. Zooplankton species differ in their trait properties (i.e. body size, clearance rate, habitat preference, feeding strategies, predator defense strategies etc.; see Barnett et al., 2007; Pomerleau et al., 2015; Gianuca et al., 2017; Rizo et al., 2017). Different ecosystem functions can be best predicted by different indices, depending upon 
different aspects of diversity. Thompson et al. (2015) found that zooplankton biomass is best predicted by zooplankton trait-based functional richness, while phytoplankton abundance, as result of the top-down effect of zooplankton, is best predicted by zooplankton phylogenetic diversity. Gianuca et al. (2016) clarified the role of body size in providing strong predictions of the top-down control of cladocerans.

Long-term changes in ecosystem structure and functioning can be easily observed in paleolimnological studies due the long time-span of such studies, which can range from decades to millennia (Smol, 2002; Nevalainen et al., 2015; Nevalainen \& Luoto, 2017). Remains of Cladocera are common in lake sediments and have been widely used in paleolimnological reconstructions (Korhola \& Rautio, 2001, Smol, 2002). Cladocerans occupy a central position in the zooplankton community since the clearance rates of cladocerans are the highest of any zooplankton (Barnett et al., 2007), resulting in a pronounced top-down effect on phytoplankton, and their becoming a vulnerable prey to their predators (top-down effect on Cladocera).

Biases can be found between the active population of cladocerans and the reconstructed community, based on its subfossil remains in the sediment (Kattel et al., 2007; Nykänen et al., 2009). These biases result mostly from the differ- ential preservation of species, as well as those biases likely to be present in a central lake core, which are attributable to transport processes from littoral source communities. In spite of the biases, several studies have also demonstrated similarities between the contemporary community and sedimented assemblages (Jeppesen et al., 2000; Davidson et al., 2007). Moreover, Davidson et al. (2007) found that the forces that act on cladoceran communities (e.g. macrophytes and fish) were essentially the same for contemporary and subfossil assemblages.

In paleolimnological reconstruction, it is very important to know about biases between contemporary and paleocommunities. An assessment of the degree of biodiversity present in lakes requires large-scale, intensive sampling campaigns, due to their heterogeneous microhabitat structures. In paleolimnological studies, in contrast to neolimnology, generally a single core is used to obtain biological proxies. Moreover, changes in species matrices (biodiversity) of this single core are used for reconstruction of environmental changes. Lakes have complex biota structures due to in-lake heterogeneity of microhabitats. It is especially valid for shallow lakes because their in-lake heterogeneity may be higher due to their extended littoral zones. Therefore, large biases may be found in the structure of cladoceran communities in paleolimnological

Table 1. Characteristics of the oxbows. Características de los galachos.

\begin{tabular}{|c|c|c|}
\hline & MT & Marótzugi-Holt-Tisza \\
\hline GPS & $\mathrm{N} 48.160748^{\circ} ;$ E $21.477610^{\circ}$ & N 48.175611; E 21.612306, \\
\hline type & natural & Artificial; cut off in 1860 \\
\hline Length (m) & 800 & 1800 \\
\hline Average width (m) & 63 & 60 \\
\hline Area (ha) & 5 & 11 \\
\hline Av. Depth (m) & 1.30 & 1.20 \\
\hline municipality & Tímár & Gávavencsellő \\
\hline Sluice to River Tisza & no & no \\
\hline
\end{tabular}




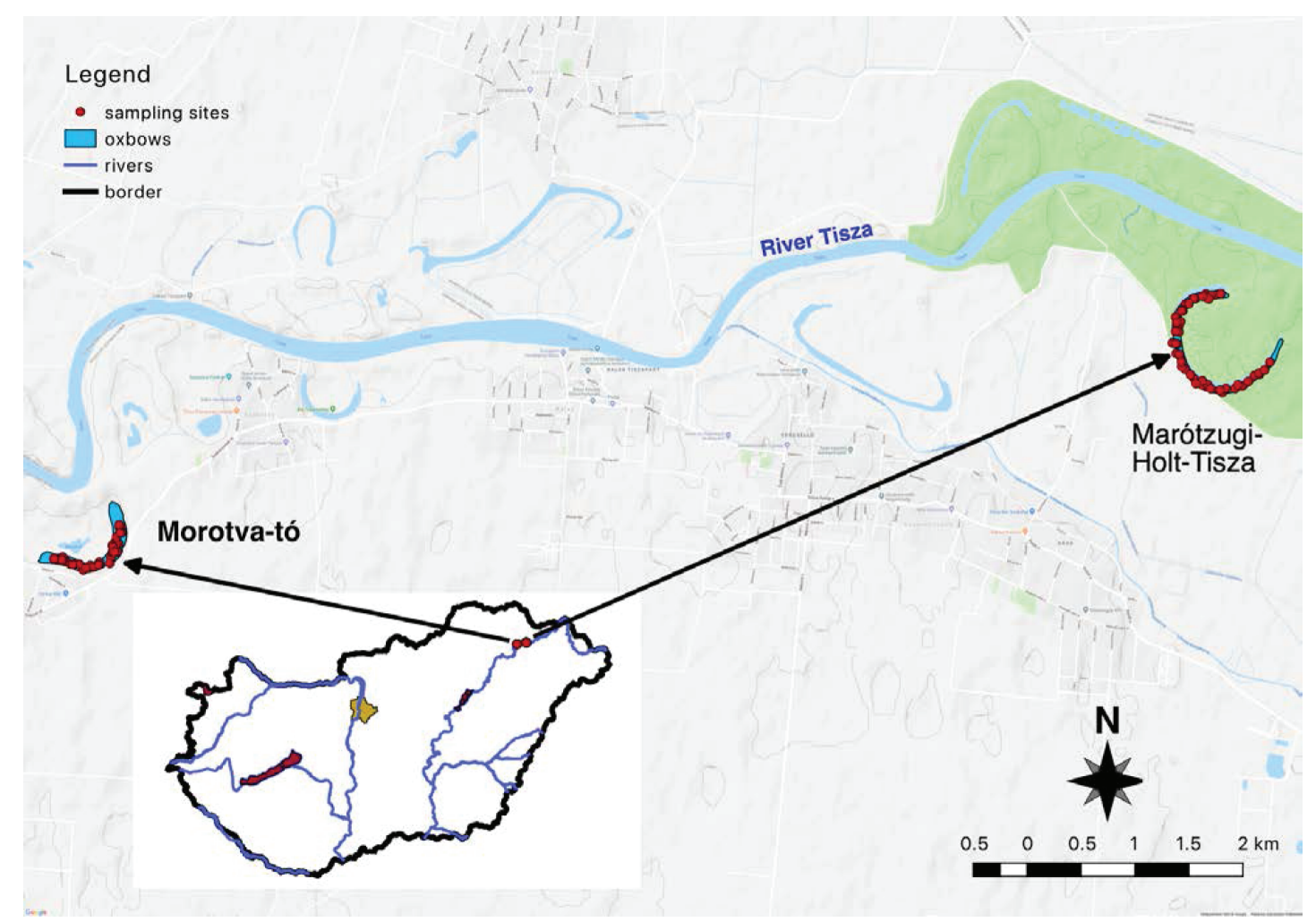

Figure 1. Map of the investigated oxbows. (Points on the maps of the oxbows represent sampling points in the course of fieldwork). Mapa del galacho estudiado. (Los puntos representan los puntos de muestro).

reconstructions of shallow lakes. Bias may originate in the differencing taphonomy of cladoceran species. Macrophyte beds favor the development of dense phytophilous Daphniidae populations (e.i. Simocephalus sp., and Ceriodaphnia sp.), while large populations of Moina sp. and Diaphanosoma sp. may be found in open waters. The weak preservation of their remains in the sediment tends to lead to the underestimation of their true proportion in the biodiversity of the lake. These biases have obvious effects on lake biodiversity assessment. Another factor is that, in spite of widespread intensive sampling efforts, only a part of benthic cladoceran species are retrieved, while the larger part of benthic species remain invisible to researchers, thus precluding any assessment of their role in biodiversity. In this pilot study the results of the intensive sampling of active cladocerans and subfossil remains of a single site in biodiversity assessments are compared.
For this pilot study two shallow oxbow lakes were chosen near the River Tisza, with the following aims: (1) to estimate how large a bias exists between contemporary and subfossil communities in these shallow lakes; (2) to determine the bias effect on the estimation of biodiversity indices; (3) to study how well the functional diversity of a paleocommunity reflects the functioning of an ecosystem, as derived from source communities.

\section{MATERIAL AND METHODS}

\section{Study area}

The River Tisza is the second largest river in Hungary. It drains an area of about $156087 \mathrm{~km}^{2}$ and has a length of $1419 \mathrm{~km}$ in Hungary. Its annual mean discharge is $792 \mathrm{~m} 3 / \mathrm{s}$, and it contributes about $14 \%$ of the Danube's total runoff 
(Sommerwerk et al., 2009). It flows through the Great Hungarian Plain. Since plains can cause a river to flow slowly, the Tisza used to follow a path with many curves and turns, which led to many large floods in the area. The regulation of the Tisza was carried out in the 19th century. In the $1860 \mathrm{~s}$, during the large river regulation program, 112 meanders were cut (Lászlóffy, 1982), shortening the river length by $474 \mathrm{~km}$, and forming a number of artificial oxbow lakes. Prior to regulation, however, oxbow lakes also formed naturally. Oxbow lakes may be divided into two categories according to their location: un-protected oxbow lakes are situated between the levees and the river, and protected ones can be found on the far side of the dykes. Since oxbows are mostly supplied by water during the flooding of the Tisza, many of them have filled up and subsequently dried out. Although the artificial meanders are much younger than the naturally formed ones, most of them have attained a similar ecological status as the older, natural oxbows (Pálfai, 2003).

Two oxbow lakes, Morotva-tó (MT) and the Marótzugi-Holt-Tisza (MHT), were selected for living and subfossil cladoceran analyses. Both lakes are small; Morotva-tó (Lake Oxbow) is located at $\mathrm{km} 555$ of river, next to the village of Timar, while the Marótzugi-Holt-Tisza (holt =

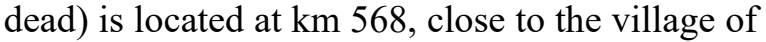
Gávavencsello on the left bank of the river (Fig. 1; Table 1.). The MT is naturally cut off, while the MHT was cut off during the canalization of the River Tisza in 1860. They also differ in terms of water supply, since the MT only fills up during the flooding of the Tisza, while the water balance of the MHT is managed by a sluice on an artificial canal from the River Tisza.

Both oxbows are unprotected from floods, since they are situated between dykes and the river channel. Although they are Nature Conservation areas, MHT is managed as fishpond. The MHT has been yearly stocked by about $100-120$ $\mathrm{kg}$ of fish, while there is no fish stocking in the MT (personal communications of the maintainers). The biota of both lakes is particularly rich, but only the MHT has been registered as a national nature reserve and wildlife sanctuary (Hortobágy National Park; Pálfai, 2003).

\section{Sampling and laboratory procedures}

For the active plankton component, the sampling design aimed at integrating seasonal and spatial variations. The oxbows were sampled twice a year (May 25 and October 13, 2005; Jun 21 and October 23, 2006; April 17 and October 23, 2007; Jun 06 and October 21, 2008). Macrophyte coverage was about $80-90 \%$ on the MT, whereas it was $\sim 50 \%$ on the MHT (mostly at the two shallow ends of the oxbow). Phragmites australis and Typha angustifolia inhabited the shoreline of both oxbows, so Trapa natans, Nuphar luteum, Ceratophyllum demersum and Myriophyllum spicatum were the dominant plants, although some microhabitats were also populated by Salvinia natans, Potamogeton amphibium, Hydrocharis morsusranae and Polygonum amphibium.

Samples were obtained for active cladoceran populations and for water quality from 15 and 16 sampling sites in the MT and MHT, respectively. Sampling sites were almost equally divided between littoral and open water (Fig. 1). Water quality samples were collected with a Meyer bottle from $1 \mathrm{~m}$ depth, and the samples of the different sites were then pooled and the resulting sample (15-16 L) was thoroughly stirred and quantitatively subsampled for water quality analyses. Active cladocerans were sampled using a self-closing tube sampler (length: $2 \mathrm{~m}$, diameter: $10 \mathrm{~cm})$ with a plankton net $(63 \mu \mathrm{m}$ mesh $)$ attached. The tube sampler is efficient in the taking of integrated plankton samples in shallow lakes; it also samples efficiently in macrophyte-beds. At each sampling site, the tube sampler was lowered to the bottom, so the entire water column (0.5-15 L, depending on depth) was filtered. Plankton samples from the different locations were pooled, resulting in the integration of within-lake variations, then they were preserved using Lugol solution. Water quality parameters $(\mathrm{pH}$, conductivity, cation, anion, nutrients, COD, TOC, Chlorophyll- $a$; see in Table 3) were determined in the Laboratory of the West Transdanubian Water Authority, following the Hungarian Water Quality Standard protocols.

Sediment cores were obtained in 2008 from the deepest part of the oxbows, and the top $2 \mathrm{~cm}$ of sediment layers was used for the subfossil 
cladoceran analysis. Since sedimentation rates are high in the oxbows of the Tisza $(0.2-1.1 \mathrm{~cm}$; Szabó et al., 2012; Korponai et al., 2016), and bioturbation has significant effect on the depth distribution of remains (Kearns et al., 1996), it was reasonable to assume that the top $2 \mathrm{~cm}$ sediment layer would represent the sampling period of active Cladocera populations in the present study.

In order to obtain a representative sample of the composition of the active cladoceran population, a minimum of 300 individuals was counted using the Utermöhl protocol. The length of the first 30 individuals of each species in each sample was measured using an ocular micrometer to an accuracy of $0.01 \mathrm{~mm}$. The community size distribution of cladocerans was determined on the basis of individual body length. $2 \mathrm{~cm}^{3}$ of sediment subsamples were deflocculated in $10 \%$ $\mathrm{KOH}$. Cladocera remains were then collected by sieving the resultant deflocculated liquid through a $35 \mu \mathrm{m}$ mesh (Frey, 1986). Only well preserved chitinous remains (headshields, carapaces, post-abdomens, post-abdominal claws, and ephippia) were considered in the determination of the density of various Cladocera species. Furthermore, fragments were counted only if unambiguous diagnostic marks were evident. The most frequent body parts of each taxon were used to estimate the abundance of individuals in terms of density (ind $/ \mathrm{cm}^{3}$ of fresh sediment). The composition of the Cladocera community was estimated on the basis of the determination of at least 300 individuals in each subsample (Korhola \& Rautio, 2001). Taxonomical identification was carried out according to work of Frey (1950), Goulden \& Frey (1963), Gulyás \& Forró (1999), Szeroczyńska \& Sarmaja-Korjonen (2007).

\section{Statistical analyses}

To compare the water quality and median cladoceran body size of the oxbows, a non-parametric ANOVA (Kruskall-Wallis) test was conducted. Water quality components were standardized to a zero mean and unit variance. The various degrees of homogeneity of the dispersion of the active cladoceran communities of both oxbows were tested and compared using "betadis- per" and "permutest" through 999 permutations. Variance partitioning in the cladoceran community was tested using the 'adonis' function. "Adonis" carries out a PERMANOVA (Permutational Multivariate Analysis of Variance Using Distance), and partitions sums of squares of a multivariate data set among sources of variation using distance matrices. In analyses the Bray-Curtis distance metric was applied to non-transformed, non-standardized cladoceran species abundance data of active communities. Following 'adonis', similarity percentages ('simper') were used to identify the species contributing most to group dissimilarity.

\section{Species, functional and phylogenetic $\alpha$-diversity}

For comparison of active and subfossil communities, we calculated the mean abundances of contemporary cladoceran species of oxbows for active communities, and these data were introduced to diversity analyses. Species diversity of the active and subfossil cladoceran assemblages was estimated using Hill's numbers (Hill, 1973) on abundances, in which N0 represents species-richness (number of taxa), N1 the Shannon-Wiener index and $\mathrm{N} 2$ the effective number of species, which is the reciprocal of Simpson's diversity index (Hill, 1973; Jost, 2006; Telford \& Birks, 2011). Values were also calculated for Pielou's evenness and the Simpson index. The Shannon-Wiener index is sensitive to dominant taxa, while the Simpson index is sensitive to rare species (Jost, 2007).

For trait diversity, the available zooplankton functional traits for all species occurring in the communities were used (Barnett et al., 2007; Pomerleau et al., 2015; Nevalainen \& Luoto, 2017; Rizo et al., 2017; Gianuca et al., 2018). Combination of Rizo's and Nevalainen's traits (Nevalainen \& Luoto, 2017; Rizo et al., 2017) was employed in the analysis, complemented by the morphological traits of postabdominal claws (Table 2). Cladocerans use the postabdomen in the rejection of particles, the cleaning of thoracic limbs, the prevention of clogging of the filter apparatus, and in locomotion. Benthic species crawl on substrata, and use their postabdomen for pushing (Smirnov, 2017). Trait distance matrices 
Table 2. Summary of functional traits used (Rizo et al., 2017, Nevalainen \& Luoto, 2017). Resumen de los rasgos funcionales utilizados.

\begin{tabular}{|c|c|c|}
\hline Trait & Type of trait & Ecological function \\
\hline $\begin{array}{l}\text { Feeding type (S-type, D-type, } \\
\text { C-type, I-type, B-type) }\end{array}$ & Morphological/behavioral & Feeding \\
\hline $\begin{array}{l}\text { Trophic regime (herbivore, } \\
\text { detritivore, predator) }\end{array}$ & Physiological & Feeding \\
\hline $\begin{array}{l}\text { Size of postabdominal } \\
\text { claws (small, intermediate, } \\
\text { large) }\end{array}$ & Morphological & Feeding \\
\hline $\begin{array}{l}\text { Type of combs in } \\
\text { postabdominal claws (no } \\
\text { combs, hairy, fine combs, } \\
\text { small teeth, mediate teeth, } \\
\text { large teeth) }\end{array}$ & Morphological & Feeding \\
\hline $\begin{array}{l}\text { Preferred trophic status } \\
\text { (oligotrophic, oligo- } \\
\text { mesotrophic, mesotrophic, } \\
\text { meso-eutrophic, eutrophic) }\end{array}$ & Physiological & Feeding \\
\hline $\begin{array}{l}\text { Swimming antennae length to } \\
\text { body size ratio }\end{array}$ & Morphological & Survival \\
\hline Eye size to body size ratio & Morphological & Survival \\
\hline $\begin{array}{l}\text { Presence of ocellus (with or } \\
\text { without) }\end{array}$ & Morphological & Survival \\
\hline $\begin{array}{l}\text { Presence of color in the } \\
\text { carapace (with or without) }\end{array}$ & Morphological & Survival \\
\hline $\begin{array}{l}\text { Development of defensive } \\
\text { structure (with or without) }\end{array}$ & Morphological & Survival \\
\hline $\begin{array}{l}\text { Predatory escape response } \\
\text { (pausing and jumping, rapid } \\
\text { swimming, not moving) }\end{array}$ & Behavioral & Survival \\
\hline $\begin{array}{l}\text { Preferred habitat (pelagic, } \\
\text { littoral, margins of } \\
\text { macrophytes) }\end{array}$ & Behavioral/Feeding & Survival \\
\hline $\begin{array}{l}\text { Shape (globular, oval, } \\
\text { elongated) }\end{array}$ & Morphological & Survival \\
\hline Average egg clutch & Morphological & Reproduction \\
\hline $\begin{array}{l}\text { Body size }(\text { small }<500 \mu \mathrm{m} \text {, } \\
\text { intermediate } 500-1000 \mu \mathrm{m} \text {, } \\
\text { large }>1000 \mu \mathrm{m}\end{array}$ & Morphological/physiological & Growth \\
\hline
\end{tabular}


using Gower's distance were calculated, because body size is a continuous variable, whereas the other traits are categorical (Borcard et al., 2011). Functional trait diversities (Mason et al., 2005) and Faith's phylogenetic diversities (Faith, 1992) were calculated using the functions "dbFD" and "pd" in packages "FD" (Laliberté \& Legendre, 2010; Laliberté et al., 2014). Faith's phylogenetic diversity is highly dependent on species richness, and so distance based phylogenetic diversity measures was chosen for use in the present study: standard effect size of mean pairwise taxon distances (sesMPD), and standard effect size of mean nearest taxon distance (sesMNTD) (Webb et al., 2002), both of which provide a measure of phylogenetic diversity that is independent of species richness. The abundance weighted measures sesMPD and sesMNTD represent the average distance between two random individuals in a sample and the average distance to the closest heterospecific individual for all individuals in the sample, respectively (Webb et al., 2008). The branch lengths on the phylogenetic tree were used as a measure of phylogenetic distance, while Gower dissimilarity was applied to obtain functional distances (Borcard et al., 2011).

Hierarchical cluster analysis was applied to the trait matrices of cladoceran communities in order to determine potential functional groups. In the analysis, the Gowdis dissimilarity function in "FD" packages (Podani, 1999; Laliberté et al., 2014) was used to compute the distance for mixed variables, and then the Ward agglomerative method was applied to attain clustering. Phylogenetic trees were created based on detailed taxonomical categories (Błędzki \& Rybak, 2016) in which Sorensen distance was used in hierarchical clustering with the complete linkage agglomerative method.

\section{Species, phylogenetic and trait $\beta$-diversity}

Sorensen and Bray- Curtis dissimilarity coefficients were calculated for the cladoceran communities of the oxbows and used as a measure of $\beta$ diversity. Sorensen dissimilarity is based on species' presence or absence, while Bray-Curtis dissimilarity is based on the abundance of species. Next, the $\beta$ - diversity was partioned into its two components, degree of nestedness and replacement, using the bray.part function of the "betapart" statistical package (Baselga \& Orme, 2012). Phylogenetic and functional $\beta$-diversity were measured using mean pairwise taxon distances (MPD) and mean nearest taxon distance (MNTD) (Webb et al., 2002). The branch lengths on the phylogenetic tree were used as a measure of phylogenetic distance, while Gower dissimilarity was applied to obtain functional distances (Borcard et al., 2011). COMDIST was used for measuring phylogenetic dispersion, and COMDIST was also used to calculate functional ß-diversity metrics based on multi-trait distance

\section{Morotva-tó}

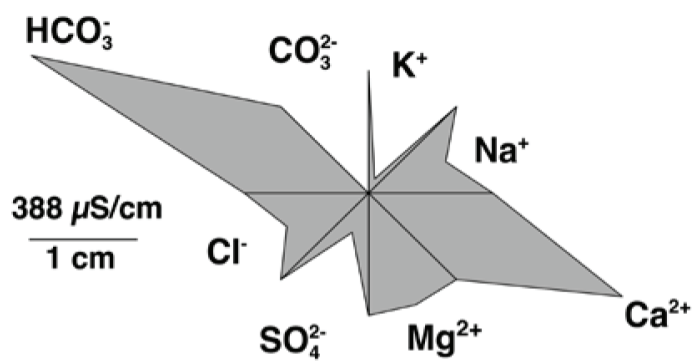

\section{Marótzugi-Holt-Tisza}

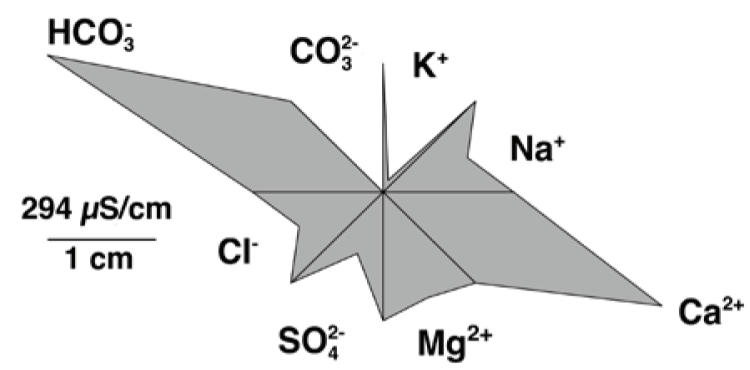

Figure 2. Maucha diagram showing the main ion composition of the two oxbows. Scale bar indicates $0.1 \mathrm{~mm}$ for all photographs. Diagrama Maucha mostrando la composición iónica principal en los dos galachos. 
matrices. The abundance values for species were used when calculating both functional and phylogenetic $\beta$-diversity. The use of COMDIST for both trait- and phylogenetically-based information allowed the use of comparable metrics for trait and phylogenetic distances (Swenson, 2014). The measures were calculated using the R package "picante" (Kembel et al., 2010) in R (R Core Team, 2017).

In spite of the apparent bias in subfossil communities it is important to investigate the relationship between the distinct diversity metrics (the number of species not included) of active and sub fossil communities. Therefore, a linear model was employed to analyze the predictive strength of the diversity metrics of the subfossil community in relation to the active. Log-transformed diversity indices $(\log (x+1))$ were entered into the model. The next step was to observe the effect of cladoceran communities (active and subfossil) or determine whether oxbows have a significant effect on the variance of diversity metrics. A linear mixed model was therefore used with type of diversity matrices as a random factor.

The degree to which the measured traits carry a phylogenetic signal was assessed using the procedures employed by Gianuca et al. (2018). First, a standard Mantel test is performed to assess the correlation between the phylogenetic distance and the functional trait distance matrices, then (if this test is significant $(p<0.05)$, the second step is to test whether such a correlation between phylogeny and traits is higher than that which might be expected by chance alone, given a specific evolutionary model (for more details, please see Debastiani \& Duarte 2017). All calculations, data analyses and visualizations were performed in R (R Core Team, 2017), using the "betapart", (Baselga \& Orme, 2012), "FD" (Laliberté \& Legendre, 2010; Laliberté et al., 2014)., "picante" (Kembel et al., 2010), and "vegan" packages (Oksanen et al., 2017).

\section{RESULTS}

\section{Water quality}

The water quality of the various oxbows was very similar in terms of common major ion composition
(Fig. 2). The $\mathrm{pH}$ varied from neutral to slightly alkaline, but conductivity was high, and significantly higher in the MT due to a higher bicarbonate concentration. Total dissolved solids (TDS) were also significantly higher in the MT, which was due to the higher concentration of $\mathrm{Na}, \mathrm{K}, \mathrm{Ca}, \mathrm{Cl}$ and $\mathrm{HCO}_{3}$ ions. Although higher concentrations of TOC (total organic carbon) were found in the MT (Table 3), $\mathrm{COD}_{\mathrm{Cr}}$ (chemical oxygen demand) varied over the same range in both oxbows.

Nutrient concentrations were also similar in both oxbows; they were mesotrophic, TP varied between 0.01 and $0.07 \mathrm{mg} / 1$ in MT, and between 0.02 and $0.06 \mathrm{mg} / \mathrm{l}$ in MHT, while chlorophyll $-a$ content varied between 3 and 8 and 3 and $14 \mu \mathrm{g} / \mathrm{l}$, respectively (Table 3 ).

\section{Cladoceran communities}

Altogether 5354 specimens were counted for active, and 1721 remains (707 specimens) were counted for subfossil community, from which 41 cladoceran species were identified. From them 23 species were common in the oxbows, while nine species were specific to each of the oxbows separately. The active cladoceran community contained almost the same species pool, while the subfossil assemblages were richer in the MT (Table 4).

\section{Active cladoceran communities}

A total of 32 cladoceran species were found in the samples, 27 in the MT and 28 in the MHT (Table 4). High degrees of variance were detected in abundance data, caused by the different times at which some species bloom (MT, 2005: Bosmina longirostris and Ceriodaphnia pulchella); MHT, 2005 and 2008: B. longirostris). B. longirostris and Chydorus sphaericus were found in great abundance in the oxbows. The following species were also abundant: $C$. pulchella, Diaphanosoma brachyurum, Coronatella rectangula, Daphnia parvula and Pleuroxus aduncus (Fig. 3). Three of these - C. pulchella, Coronatella rectangula and $P$. aduncus occurred in the highest numbers in the MT, while $D$. brachyurum and D. parvula were found in the MHT (Fig. 3). The occurrence of twenty-one 
species was shared between the two oxbows (Table 4). Variance of the abundance of active communities of oxbows was homogenous (betadisper: $\mathrm{F}=1.2801, p=0.269)$, therefore the differences in the communities between the oxbows were tested for. The result revealed that the dissimilarities in active cladoceran communities were significant between the two oxbows

Table 3. Water quality parameters of the oxbows, and results of Kruskall-Wallis test for differences between the oxbows. Parámetros de calidad del agua de los galachos y resultados del test Kruskall-Wallis entre galachos.

\begin{tabular}{|c|c|c|c|c|c|c|c|c|c|}
\hline & \multicolumn{3}{|c|}{ MT } & \multicolumn{3}{|c|}{ Marótzugi-Holt-Tisza } & \multicolumn{3}{|c|}{ Kruskall-Wallis } \\
\hline & $\min$ & mean & $\max$ & $\min$ & mean & $\max$ & $\chi^{2}$ & df & $p$ \\
\hline HCO3 (mg/l) & 176 & 215.63 & 278 & 126 & 152 & 168 & 11.294 & 1 & 0.001 \\
\hline TDS (mg/l) & 185 & 257.25 & 326 & 140 & 185.88 & 262 & 6.362 & 1 & 0.012 \\
\hline cond $(\mu \mathrm{S} / \mathrm{cm})$ & 293 & 387.75 & 477 & 244 & 293.75 & 337 & 6.1 & 1 & 0.014 \\
\hline $\mathrm{Ca}(\mathrm{mg} / \mathrm{l})$ & 39 & 51.25 & 59 & 35 & 41.75 & 52 & 5.625 & 1 & 0.018 \\
\hline $\mathrm{Cl}(\mathrm{mg} / 1)$ & 16 & 30.38 & 41 & 12 & 22.13 & 27 & 5.121 & 1 & 0.024 \\
\hline TOC (mg/l) & 5.6 & 7.09 & 9 & 4.8 & 5.82 & 7.1 & 4.412 & 1 & 0.036 \\
\hline $\mathrm{K}(\mathrm{mg} / \mathrm{l})$ & 3.2 & 5.74 & 15.6 & 2.4 & 3.54 & 4.9 & 4.219 & 1 & 0.04 \\
\hline $\mathrm{SS}(\mathrm{mg} / 1)$ & 0 & 2.61 & 10 & 0.1 & 9.48 & 29 & 4.231 & 1 & 0.04 \\
\hline $\mathrm{Na}(\mathrm{mg} / \mathrm{l})$ & 12 & 17.875 & 25 & 9 & 14.5 & 18 & 3.052 & 1 & 0.081 \\
\hline $\operatorname{Mg}(\mathrm{mg} / \mathrm{l})$ & 2.2 & 13.9 & 26 & 8 & 9.75 & 14 & 2.53 & 1 & 0.112 \\
\hline TDP (mg/l) & 0.006 & 0.018 & 0.038 & 0.006 & 0.026 & 0.058 & 2.184 & 1 & 0.139 \\
\hline Chl-a $(\mu \mathrm{g} / 1)$ & 3 & 5.63 & 8 & 3 & 9.25 & 14 & 2.04 & 1 & 0.153 \\
\hline TN (mg/l) & 0.57 & 0.82 & 1.05 & 0.46 & 0.73 & 1.04 & 1.337 & 1 & 0.248 \\
\hline DIN (mg/l) & 0.04 & 0.075 & 0.107 & 0.056 & 0.096 & 0.173 & 0.799 & 1 & 0.371 \\
\hline $\mathrm{COD}_{\mathrm{Cr}}(\mathrm{mg} / \mathrm{l})$ & 7.5 & 19.88 & 36 & 7.5 & 17.63 & 29 & 0.344 & 1 & 0.557 \\
\hline Mn (mg/l) & 0 & 0.03 & 0.18 & 0.005 & 0.016 & 0.07 & 0.147 & 1 & 0.702 \\
\hline TP (mg/l) & 0.006 & 0.038 & 0.071 & 0.02 & 0.037 & 0.064 & 0.025 & 1 & 0.875 \\
\hline $\mathrm{pH}$ & 7.1 & 7.56 & 8 & 7.1 & 7.55 & 8.1 & 0.012 & 1 & 0.914 \\
\hline DIP (mg/l) & 0.002 & 0.011 & 0.032 & 0.002 & 0.013 & 0.047 & 0.012 & 1 & 0.914 \\
\hline SO4 (mg/1) & 12.5 & 20.12 & 54 & 12.5 & 22.25 & 59 & 0.003 & 1 & 0.955 \\
\hline $\mathrm{Fe}(\mathrm{mg} / \mathrm{l})$ & 0 & 0.05 & 0.17 & 0.005 & 0.03 & 0.06 & 0 & 1 & 1 \\
\hline Secchi depth (cm) & 56 & 92 & 125 & 28 & 62 & 95 & 42.216 & 1 & $<0.001$ \\
\hline
\end{tabular}


Table 4. List of species occurring in source and sediment samples in the oxbows. (+: present; -: absent; e: ephippia only). Lista de especies presentes en las muestras de origen y de sedimento en los galachos.

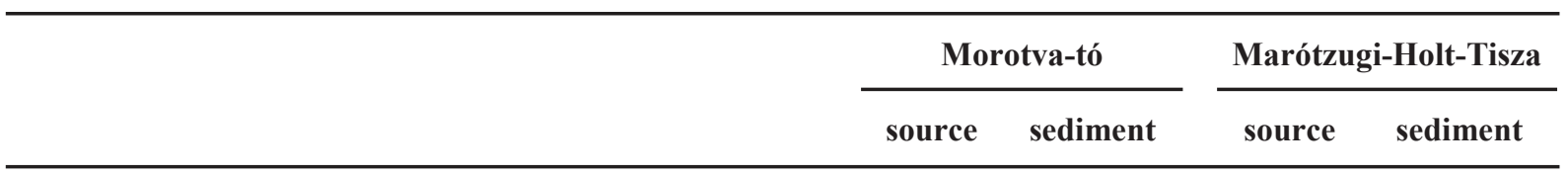

\section{dominant species}

Bosmina longirostris (O. F. Müller, 1776)

Chydorus sphaericus (O. F. Müller, 1776)

\section{species in Marótzugi-Holt-Tisza}

Moina micrura Kurz, 1875

Daphnia ambigua Scourfield 1947

Disparalona rostrata (Koch, 1841)

Ceriodaphnia laticaudata P. E. Müller, 1867

Alonella excisa Fischer, 1854

Camptocercus rectirostris (Schödler, 1862)

Leydigia leydigi (Schödler, 1863)

Ceriodaphnia dubia Richard, 1894

Alona costata Sars, 1862

\section{species in MT}

Simocephalus serrulatus (Koch, 1841)

Alonella nana (Baird, 1843)

Monospilus dispar Sars, 1862

Scapholeberis mucronata (O. F. Müller, 1776)

Eurycercus lamellatus (O. F. Müller, 1776)

Pseudochydorus globosus (Baird, 1843)

Alona quadrangularis (O. F. Müller, 1776)

Leydigia acanthocercoides (Fischer, 1854)

Oxyurella tenuicaudis (Sars, 1862)

\section{common species}

Ceriodaphnia pulchella Sars, 1862

Coronatella rectangula Sars, 1862

Diaphanosoma brachyurum (Liévin, 1848)

Daphnia parvula Fordyce, 1901

Pleuroxus aduncus (Jurine, 1820)

Acropterus harpae (Baird, 1834)

Simocephalus vetulus (O. F. Müller, 1776)

$\begin{array}{lllll}+ & + & + & + & + \\ + & + & + & + & +\end{array}$

e

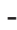

$+$

$+$
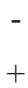

Cont. 
Table 4. (cont.)

Alonella exigua (Lilljeborg, 1853)

Ceriodaphnia quadrangula (O. F. Müller, 1785)

Daphnia galeata Sars, 1863

Pleuroxus truncatus (O. F. Müller, 1785)

Pleuroxus trigonellus (O. F. Müller, 1776)

Pleuroxus laevis Sars, 1862

Alona affinis (Leydig, 1860)

Alona guttata Sars, 1862

Graptoleberis testudinaria (Fischer, 1848)

Simocephalus expinosus (De Geer, 1778)

Ceriodaphnia reticulata (Jurine, 1820)

Bunops serricaudata (Daday, 1884)

Alona intermedia Sars, 1862

Iliocryptus sordidus (Liévin, 1848)

\begin{tabular}{llll}
+ & + & + & - \\
+ & - & + & - \\
+ & - & + & - \\
+ & + & + & - \\
+ & + & + & - \\
+ & + & + & + \\
+ & + & + & + \\
+ & + & - & + \\
+ & + & + & + \\
+ & - & + & - \\
+ & + & + & - \\
+ & - & + & - \\
+ & + & + & - \\
+ & - & + & - \\
\hline
\end{tabular}

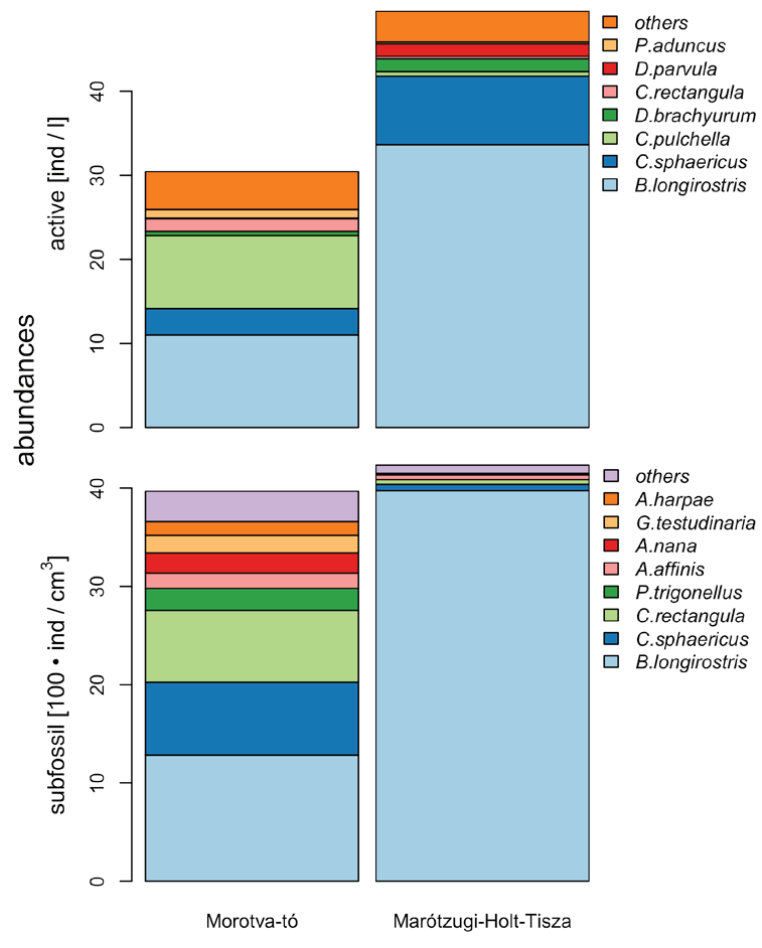

Figure 3. Cumulative abundances of dominant cladoceran species in the oxbows. Abundancia acumulada de las especies dominantes de cladóceros en los galachos.
(Permanova: $\mathrm{F}_{\text {model }}=2.93, \mathrm{R}^{2}=0.173, p=$ 0.007). The SIMPER analysis identified a decreasing order, in which $B$. longirostris, $C$. pulchella and $C$. sphaericus contributed most to the dissimilarity between oxbows. The high abundance of $B$. longirostris and $C$. spharicus in MHT was responsible for dissimilarities of $50 \%$ and $10 \%$, respectively, while the high abundance C. pulchella contributed $17 \%$ of the total dissimilarity of the MT. Due to the dominance of small bodied cladocerans, average cladoceran body size was small in both oxbows (MT: $0.443 \mathrm{~mm}$ (n = 892), MHT: $0.383 \mathrm{~mm}(\mathrm{n}=814))$, but it was significantly smaller in the MHT (Kruskal-Wallis test: $\left.\chi^{2}=12.346, \mathrm{df}=1, p<0.001\right)$. Although the average body sizes of both dominant species (Bosmina longirostris, and Chydorus sphaericus) were significantly smaller in the MHT (Bosmina longirostris: MHT: $0.268 \mathrm{~mm}, \mathrm{MT}: 0.290$ mm, Kruskal-Wallis test: $\chi^{2}=15.162, \mathrm{df}=1, p<$ 0.001; Chydorus sphaericus: MHT: $0.278 \mathrm{~mm}$, MT: $0.293 \mathrm{~mm}$, Kruskal-Wallis test: $\chi^{2}=5.3082$, $\mathrm{df}=1, p=0.02)$, the proportion of large cladocerans $(1 \mathrm{~mm}=<)$ played a significant role in the body size spectra of cladocerans in the MT (Fig. 4). 
Marótzugi-Holt-Tisza

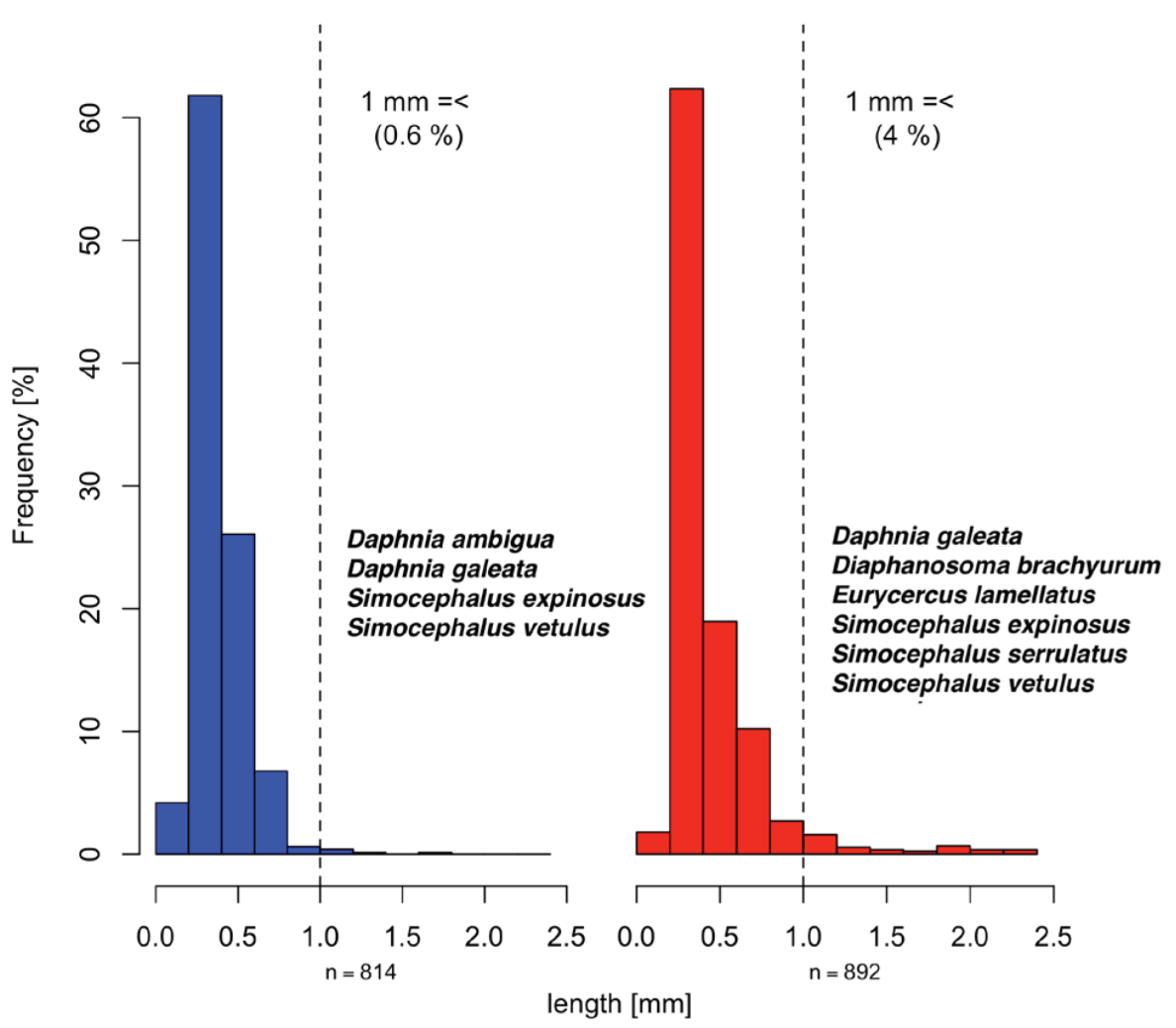

Figure 4. Body size distribution of cladoceran communities. Distribución de tamaño de la comunidad de cladóceros.

\section{Subfossil cladocerans}

Remains of a total of 23 cladoceran species were found in the sediment samples, of which 18 species occurred in the MT, and 13 in the MHT (Table 4.). Most of the remains belonged to the dominant species Bosmina longirostris, Chydorus spharicus, and Coronatella rectangula in both oxbows. More remains of B. longirostris were found in the MHT, whereas those of $C$. rectangula and Chydorus spaericus were most numerous in the MT.

As found in the active cladoceran communities, differences were also found in the subfossil communities of the two oxbows. The remains of Alonella nana, Monospilus dispar, Alona quadrangularis, Leydigia acanthocercoides and Oxyurella tenuicaudis were found in the MT exclusively, while the remains of Leydigia leydigi,
Alona costata and Ceriodaphnia ephippia only occurred in the MHT (Table 4). A simper analysis revealed that $B$. longirostris, and $C$. rectangula and $C$. sphaericus contributed to the dissimilarity of the cladoceran communities in the oxbows. A greater abundance of $B$. longirostris in the MHT accounted for the greatest proportion $(51 \%)$ of the total dissimilarity between the oxbows, while the remains of $C$. rectangula and $C$. sphaericus were found in a higher numbers in the MT, and thus they contributed $13 \%$ and $12 \%$ to the total dissimilarity, respectively.

\section{Diversity}

Homogenous dispersion of contemporary data allowed merging the active and subfossil species sets, altogether 32 species composed the pooled community of the oxbows. The active community 
Table 5. Diversity indices of cladoceran communities in the oxbows. (higher values are in bold.). Índices de diversidad de las comunidades de cladóceros en los galachos(los valores más altos están en negrita).

\begin{tabular}{lccccc}
\hline & \multicolumn{2}{c}{ Morotva-tó } & & \multicolumn{2}{c}{ Marótzugi-Holt-Tisza } \\
\cline { 2 - 3 } \cline { 5 - 6 } nbsp & source & sediment & & source & sediment \\
sing.sp & 27.000 & 18.000 & & 28.000 & 13.000 \\
FRic & 27.000 & 18.000 & & 28.000 & 13.000 \\
qual.FRic & 0.979 & 0.927 & & $\mathbf{0 . 9 8 1}$ & 0.770 \\
FEve & 0.580 & 0.726 & & 0.580 & 0.726 \\
FDiv & $\mathbf{0 . 5 4 2}$ & 0.547 & & 0.498 & $\mathbf{0 . 6 8 9}$ \\
FDis & $\mathbf{0 . 9 4 9}$ & 0.834 & & 0.877 & $\mathbf{0 . 9 8 5}$ \\
RaoQ & $\mathbf{0 . 2 7 8}$ & $\mathbf{0 . 2 4 6}$ & & 0.193 & 0.063 \\
Shannon & $\mathbf{0 . 0 8 3}$ & $\mathbf{0 . 0 6 9}$ & & 0.059 & 0.018 \\
J & $\mathbf{1 . 9 5 8}$ & $\mathbf{2 . 0 5 1}$ & & 1.254 & 0.363 \\
Simpson & $\mathbf{0 . 0 7 3}$ & $\mathbf{0 . 1 1 4}$ & & 0.045 & 0.028 \\
N2 & $\mathbf{0 . 7 7 1}$ & $\mathbf{0 . 8 1 5}$ & & 0.509 & 0.118 \\
PD & $\mathbf{4 . 3 6 6}$ & $\mathbf{5 . 4 0 3}$ & & 2.035 & 1.134 \\
sesMPD.P & $\mathbf{0 . 1 7 6}$ & $\mathbf{1 . 7 5 5}$ & & 3.056 & 1.528 \\
sesMNTD.P & 0.252 & 0.280 & & 0.325 & 0.068 \\
sesMPD.T & $\mathbf{0 . 3 4 6}$ & $\mathbf{0 . 2 9 4}$ & $\mathbf{0 . 4 4 5}$ & $\mathbf{0 . 5 5 1}$ \\
sesMNTD.T & 0.166 & 0.186 & 0.237 & 0.064 \\
\hline
\end{tabular}

consisted of 27 and 28 species in the MT and MHT, respectively. The larger part of the active communities (MT: $50 \%$ and MHT: $60 \%$ ) did not leave any remains in the sediment. In contrast to active communities, only five (MT) and four (MHT) species were exclusively found in subfossil remains. Consequently, 13 species were recorded from remains and from plankton samples in the MT, while nine species were found in plankton and sediment samples in the MHT. Although the species composition of the active cladoceran communities was similar, $20 \%$ species are not shared between the two oxbows, the species diversity components of active communities were higher in the MT (Table 5). Subfossil cladocerans were represented by fewer species, and the communities of the two oxbows were noticeably unalike. Fewer species were identified in the subfossil community in the MHT, moreover the proportion of not-shared species exceeded the number of local species. All species diversity indices were higher in the MT
(Table 5). The functional diversity of the active community was quite similar in both oxbows. Functional richness was similar, but the other components of functional diversity, except functional divergence (FDiv), were higher in the MHT (Table 5). All functional diversity indices of the subfossil community, except functional evenness (FEve) and functional divergence (FDiv) were also higher in the MT (Table 5). Faith's phylogenetic diversity was higher in both active and subfossil communities in the MT (Table 5).

All distance-based phylogenetic diversity metrics indicated a higher degree of diversity of the active community of the MT. This not was true of the subfossil community of the MHT, where a higher sesMNTD was found. Significantly fewer species were found here, thus absent species tended to decrease the sesMPD, but increase the sesMNTD, increasing the distance between the closest relatives in the phylogenetic tree. This was observed when sesMPD and sesMNTD were used for trait diversity (Table 5). 
A linear model revealed that the subfossil communities correctly predicted the diversity metrics of the active community. A significant relationship was found in both oxbows, but it was stronger in the case of the MT (MHT: $\mathrm{R}^{2}=0.709$, $\mathrm{F}_{1,13}=35, p<0.001 ;$ MT: $\mathrm{R}^{2}=0.923, \mathrm{~F}_{1,13}=168$, $p$ - <0.001). The linear mixed model revealed that both oxbows had a significant effect on diversity indices (community: $\mathrm{F}_{1,42}=2.41, p=0.128$;

\section{Functional groups}

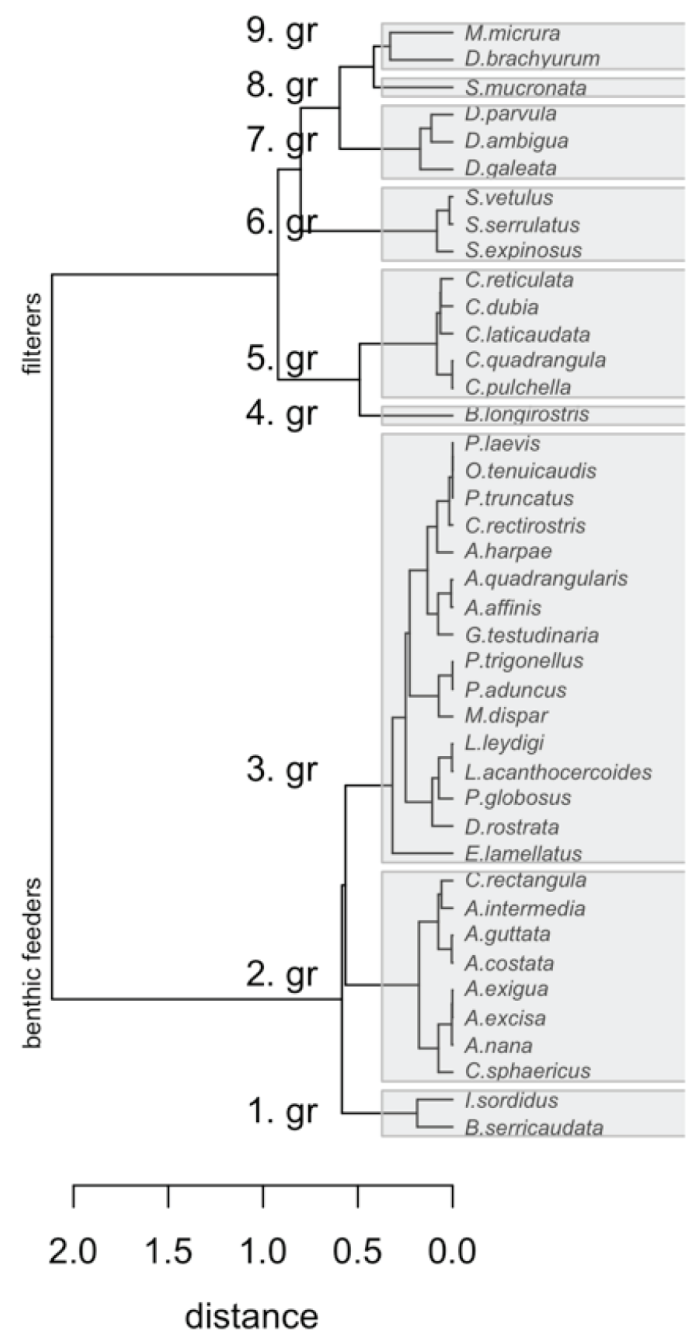

oxbow: $\mathrm{F}_{1,42}=7.88, p=0.008$; type:oxbow: $\mathrm{F}_{1,42}$ $=1.48, p=0.229)$. The cladoceran communities of the two oxbows presented a high degree of similarity ( $\beta_{\text {SOR.A }}=0.2$ and $\beta_{\text {SOR.S }}=0.4839$ for active (A) and subfossil communities (S), respectively), but abundances significantly increased $\beta$-diversity $\left(\beta_{\mathrm{BC} . \mathrm{A}}=0.572 ; \beta_{\mathrm{BC} . \mathrm{S}}=0.6379\right)$. A high portion of common species was found that was expressed in low turnover and low nestedness components

\section{Phylogenetic tree}

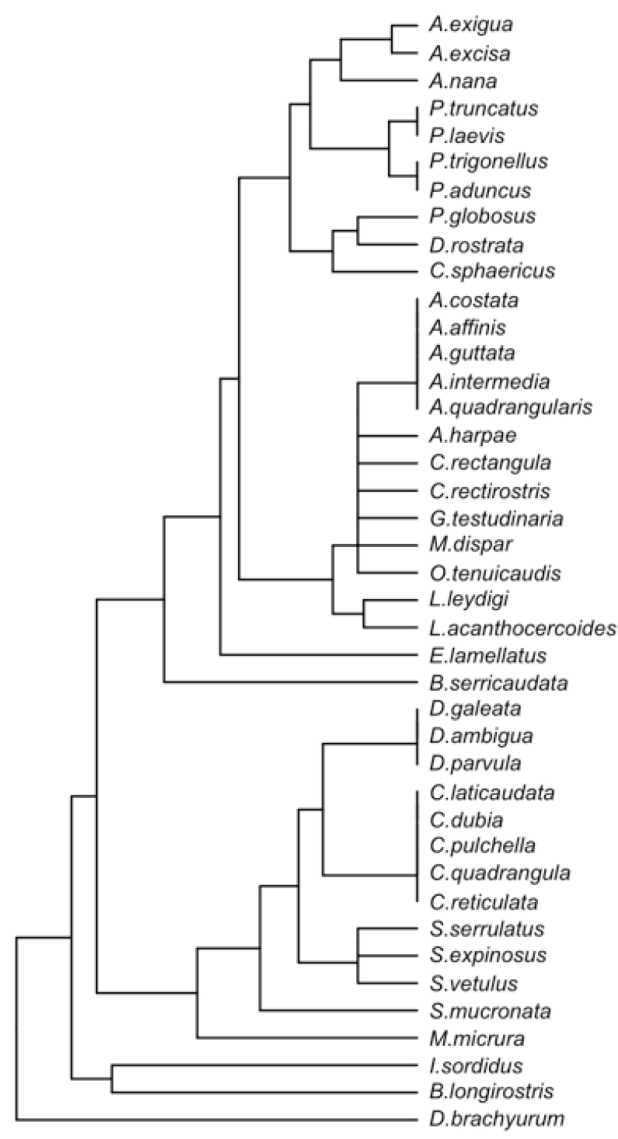

Figure 5. Functional dendrogram (left panel) and phylogenetic tree (right panel) of compound cladocera communities. Taxonomy based on Błędzki \& Rybak (2016). Branch lengths are representative only, and do not represent quantitative values. Dendrograma funcional (panel izquierdo) y árbol filogenético (panel derecho) de la composición de la comunidad de cladóceros. 


\section{Functional groups source community}

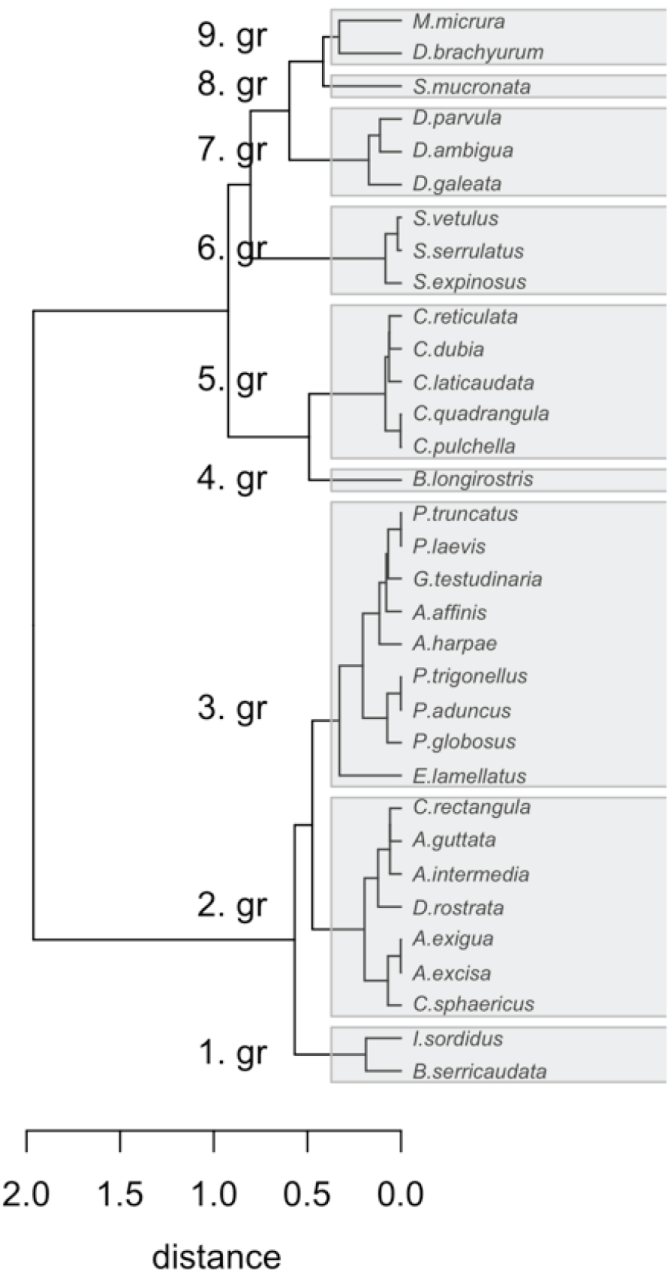

\section{Functional groups subfossil community}

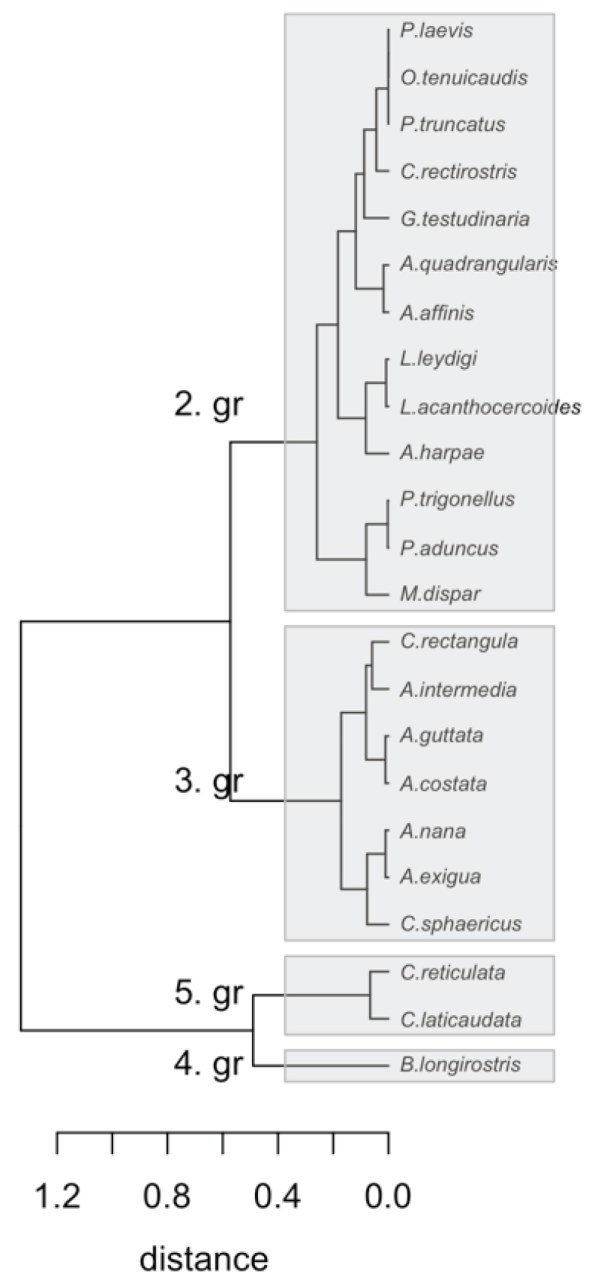

Figure 6. Functional dendrogram of active (left panel) and subfossil (right panel) communities. Dendrograma funcional de las comunidades activas (panel izquierdo) y subfósiles (panel derecho) de cladóceros.

(turnover: $\beta_{\text {SIM.A }}=0.1852, \beta_{\text {SIM.S }}=0.3846$; nestedness: $\beta_{\text {SNE.A }}=0.0148, \beta_{\text {SNE.S }}=0.0993$ ) of $\beta$-diversity. The abundance component of $\beta$-diversity revealed the importance of abundant species, since the balanced variation components of $\beta$-diversity have high values $\left(\beta_{\text {BC.BAL.A }}=0.4382\right.$, $\beta_{\text {BC.BAL.S }}=0.6258$ ). The abundance-gradient component of $\beta$-diversity of the subfossil communities $\left(\beta_{\text {BC.GRA.S }}=0.012\right)$ was lower than that of the active community ( $\beta_{\text {BC.GRA.A }}=0.134$ ), indicating a low degree of nestedness in the subfossil cladoceran community. The oxbows presented higher degrees of dissimilarity in the phylogenetic structures of active communities $\left(\right.$ COMDIST $\left._{\text {active }}=0.515\right)$ than the subfossil one $\left(\mathrm{COMDIST}_{\text {subfossil }}=0.436\right)$.

\section{Functional groups}

Nine functional groups were established for cladocerans (Fig. 5). The two main branches correspond to the feeding modes of those 
species. Filterers (herbivorous species) were further subdivided into six groups: small planktonic bacteria feeders (Gr. 4, Bosmina); small littoral daphnid filterers (Gr. 5, Ceridaphnia); littoral large filterers (Gr. 6, Simocephalus); pelagic large filterers (Gr. 7, Daphnia); littoral hyponeuston scrapers (Gr. 8, Scapholeberis) and pelagic non-daphnid filterers (Gr. 9, Diaphanosoma and Moinidae). The benthic feeder (detritivorous-herbivorous) group is comprised of a cluster of benthic pickers (Gr. 1, Ilyocryptidae and Macrothricidae) and substratum scrapers (Chydoridae). The latter group may be further divided into two groups in terms of body length: small substratum scrapers (Gr. 2, small Chydorinae and small Aloninae), and large substratum scrapers (Gr. 3, large Aloninae and large Chydorinae; (Fig. 5).

All nine functional groups were represented in the active communities, while the subfossil communities shared only four groups (Fig. 6). In the MT, small planktonic bacteria feeders accounted for the highest portion of the cladoceran community (44\%); the next group, small littoral filterers, for $27 \%$, large benthic scrapers for $20 \%$, small benthic scrapers for $5 \%$, large littoral filterers for $2.5 \%$, and large planktonic filterers for only $1 \%$ of the cladoceran community. In the MHT, small planktonic bacteria feeders made up the major proportion $(77 \%)$ of the active cladoceran community. Large benthic scrapers (17\%), small littoral filterers and small benthic scrapers accounted for $15 \%$ each, and small planktonic filterers made up $2 \%$ of the source community (Fig. 7). The abundance of the subfossil community was not equally shared between the three functional groups. The prevalence of small planktonic bacteria feeders was overwhelming, at $94 \%$, while large and small benthic scrapers made up the remainder in equal proportions (Fig. 7).

A standard Mantel test revealed strong correlation between trait and phylogenetic distances (active: mantel $\mathrm{r}=0.715, p<0.001$; subfossil: mantel $\mathrm{r}=0.845, p<0.001)$. In addition, an EM-Mantel test indicated that the following traits are more conserved along the phylogeny than might be expected in a Brownian motion evolutionary model $(p<0.05)$ : swimming antennae

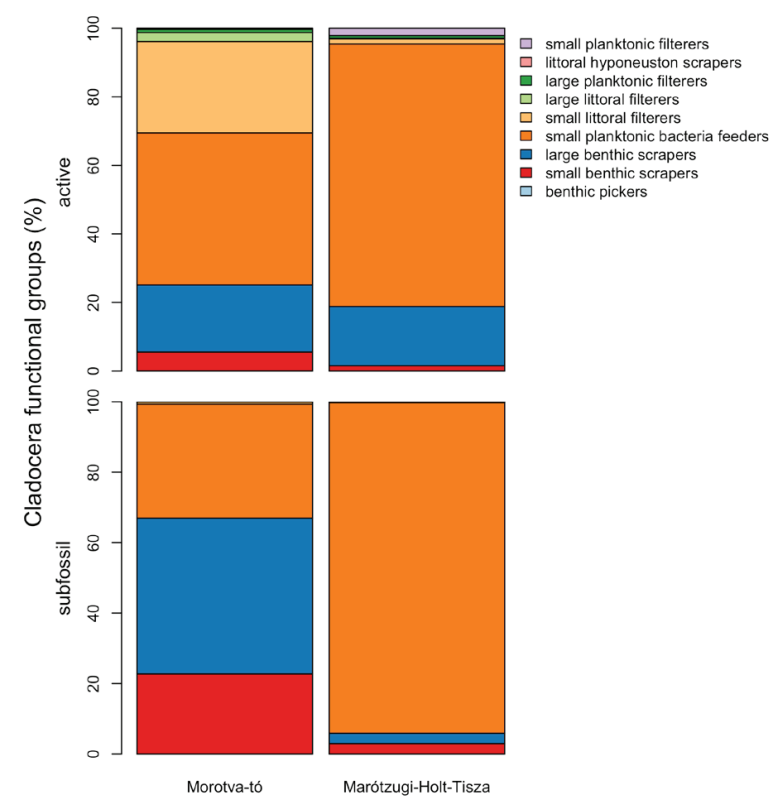

Figure 7. Prevalence of cladoceran functional groups in the oxbows. Predominio de los grupos funcionales de cladóceros en los galachos.

length, predatory escape response, ocellus presence, colored carapace, feeding type and trophic regime.

\section{DISCUSSION}

Both the Morotva-tó (MT) and Marotzugi-Holt-Tisza (MHT) are situated on the floodplain of the River Tisza. They can be filled either indirectly by groundwater, or directly by sluice from the main channel of the river (Babka et al., 2011). Correspondingly, the water ion composition of the two oxbows is almost identical due to the effect of the River Tisza (Fig. 2; Table 2). Babka \& Szabó (2007) found that the nutrients of unprotected oxbows were within the range of those to be found in the River Tisza. The nutrient contents were low (Table 3 ) in both investigated oxbows; consequently low chlorophyll- $a$ content was measured, and so the aquatic ecosystems of the oxbows may be said to be under mesotrophic conditions. Although the chlorophyll- $a$ concentration in the oxbows did not differ significantly, its average content was higher and varied over a 
wider range in the MHT; moreover, lower transparency was measured in this oxbow (Table 3 ). This phenomenon can be explained by the different trophic structure of the two oxbow ecosystems.

Differences in cladoceran communities in the waterbodies can be explained by nutrients (algae) and predators (invertebrate or/and fish). Invertebrate predators significantly increase the size of cladocerans, while fish decrease it. The mean cladoceran body size was smaller, and large cladocerans $(1 \mathrm{~mm}=<)$ occupied a negligible part (less than $1 \%$ ) of the body size spectrum in the MHT (Fig. 6), demonstrating the effects of fish predation pressure on the cladoceran community. Besides the effect on the size distribution, fish exhibit a strong effect on the structure of the species composition of cladoceran community, as well (Brooks \& Dodson, 1965; Dodson, 1974). Small sized cladoceran species (Bosmina, small daphnids and Chydorus sphaericus) will spread and become dominant in the cladoceran community under high fish predation pressure (Christoffersen et al., 1993). In the studied oxbows Bosmina longirostris and Chydorus spaericus were the dominant species. These species are very common and abundant in shallow waters and in the littoral zone, and could not be considered as an indicator of the dimensions of the pelagic zone (Hofmann, 1983, Vijverberg \& Boersma, 1997, Błędzki \& Rybak, 2016). Populations of these species were two ( $C$. sphaericus) or three (B. longirostris) times higher in the MHT than in the MT, while their median body size was smaller in the MHT.

High macrophyte coverage could also be considered evidence of low fish stocks. Many papers have revealed that macrophyte expansion follows fish reduction in shallow lakes (Jeppesen et al., 1997; Scheffer, 2001; Lauridsen et al., 2003; Davidson et al., 2010; Sayer et al., 2010). Moreover, biomanipulation experiments have also revealed that a reduction in planktivorous fish populations increases water transparency, since dense zooplankton filters out phytoplankton, causing a clear water phase (Lauridsen et al., 2003; Jeppesen et al., 2007, 2012; Nykänen et al., 2010). Secchi depths in the MT were significantly higher (Table 3), also suggesting a lower plank- tivorous fish stock. Macrophytes can stabilize the clear water phase and extended macrophyte beds are preferred habitats for phytophylous cladoceran species such as Simocephalus expinosus, $S$. serrulatus or Eurycercus lamellatus, which occurred exclusively in the MT. Other phytophylous cladocerans such as Acroperus harpae, Alona affinis, A. guttata, Graptoleberis testudinaria, and Pleuroxus species (except $P$. truncatus) indicated macrophyte habitats in both oxbows, but their greater abundance corresponded to the expanded (80-90\% coverage) macrophyte beds in the MT. Such thermophylous planktonic cladocerans as Diaphanosoma brachiurum occurred in greater numbers in the MHT, while Moina micrura was found in the MHT only; therefore, their presence was related to open water (macrophyte coverage $\sim 50 \%$ ) in this oxbow. The occurrence of ceriodaphnids in both oxbows also indicates macrophyte belts; however, higher abundances of ceriodaphnids indicate higher macrophyte cover in the MT (Fig. 3). Consequently, the results of the investigation of body size distribution, macrophyte coverage and species composition of cladocerans indicate differences in fish predation pressure between the two oxbows (Christoffersen et al., 1993, Vijverberg \& Boersma, 1997; Nevalainen \& Luoto, 2017). It was therefore concluded that the fish stock was probably higher in the MHT oxbow.

The functional structure of cladoceran communities may be a better predictor of ecosystem functioning than the taxonomical (Schleuter et al., 2010; Nevalainen \& Luoto, 2017; Nevalainen et al., 2018). Nine functional groups were distinguished in the species pool of the oxbows (Fig. 4). This structure presents a strong evolutionary background. A majority of the traits is phylogenetic in origin. For example, the structures of thoracic limbs are morphological traits in the systematics of cladocerans (DeMott \& Kerfoot, 1982; Barnett et al., 2007; Dumont, 2016). Moreover, these are a part of the filtering apparatus, and therefore may be considered a feeding trait (Rizo et al., 2017). The transparency of the cladoceran body, and its helmets, swimming speed and size of eye are all connected with the cladocerans' defensive strategy against predators (Zaret \& Kerfoot, 1975; Spaak, 1997; Boersma et 
al., 1998; Rhode et al., 2001; Kappes \& Sinsch, 2002; Kerfoot \& Weider, 2004; Laforsch \& Tollrian, 2004; Sakamoto \& Hanazato, 2008; Litchman et al., 2013).

Chydorids and bosminids comprised the greater part of cladocerans in terms of abundance and the traits shared by the most abundant species. Bosmina longirostris was the most abundant planktonic species in active and subfossil communities, and its abundance was higher in the MHT, therefore its evolutionary conserved traits (transparency, specific feeding type, no-ocellus, small body) became the dominant traits in this oxbow (Gianuca et al., 2018). The functional trait diversity indices of the active and subfossil communities were generally high in both oxbows, but they were a little higher in the MT. Functional diversity indices revealed that the cladoceran community in the MT has a more complex trait structure. The degree of functional divergence indicates the presence to some extent of niche differentiation, and thus resource competition. Communities with high functional divergence may therefore have increased levels of ecosystem function as a result of more efficient resource use (Mason et al., 2005). Functional divergence is therefore sensitive to extremities in abundance. The occurrence of the most abundant species leads to extremities in functional traits. Bosmina longirostris, Chydorus sphaericus and Diaphanosoma brachyurum were the most abundant species in the active communities of both oxbows, but they were the only species represented by high abundance ( $>33,8$ and 1.5 ind/l, respectively) in both oxbows, while the abundance of these species was much lower $(\sim 10,3$ and $0.4 \mathrm{ind} / \mathrm{l})$ in the MT. Furthermore, Ceriodaphnia pulchella, Coronatella rectangular and Pleuroxus aduncus also occurred in considerable numbers (their abundances varied between $\sim 9$, 1.5 , and $1 \mathrm{ind} / 1$ respectively). The above mentioned cladocerans represent distinct trait matrices and phylogenetic background, and so they played a significant role in the degree of functional divergence in the source community in this oxbow. The degree of functional divergence of the subfossil community was also high, and even higher than the active community in the MHT, since $B$. longirostris was the only species with extremely high abundance ( $\left.3975 \mathrm{ind} / \mathrm{cm}^{3}\right)$. The abundance of the rest of the cladocerans did not exceed $10 \mathrm{ind} / \mathrm{cm} 3$ in this oxbow. B. longirostris was the most abundant cladoceran in the MT, similarly to the source community. The functional divergence of subfossil communities in this oxbow was lower, due to seven more species occurring in high abundance (> $\left.100 \mathrm{ind} / \mathrm{cm}^{3}\right)$ (Table 5). Functional dispersion is the weighted mean distance of individual species to the centroid of all species in a given trait space, in which the weights are species relative abundances (Laliberté and Legendre, 10). In the trait space the centroid moves toward the species with highest abundance, reducing the distance of this species from the centroid, and functional dispersion also decreases. In the MHT, $B$. longirostris had an extremely high abundance, and so it decreased the FDis of both active and subfossil communities of the oxbow. In the MT, more species had high abundances, so species with high abundance could not attract the centroid toward themselves, and the FDis of the active and subfossil community were higher (Table 5).

Faith's phylogenetic diversities of both cladoceran communities were higher in the MT, since the communities were composed of phylogenetically distinct species (Table 5). Since PD is highly dependent on species richness, and subfossil cladoceran communities had lower species richness, the low PD in oxbows corresponds to the low degree of species richness in their subfossil communities. All distance based phylogenetic diversity metrics presented higher degrees of diversity of the active community of the MT. This not was true of the subfossil community of the MHT, where a higher sesMNTD was found. Significantly fewer species were found here, thus absent species decreased the sesMPD, but increased the sesMNTD, increasing the distance between the closest relatives in the phylogenetic tree. This was observed when sesMPD and sesMNTD were used for trait diversity (Table 5).

Subfossil communities display a bias in community structure compared to active communities, mainly due to taphonomy and habitat heterogeneity (Korhola \& Rautio, 2001; Kattel et al., 2007; Nevalainen, 2011). Planktonic species are under- 
represented in the subfossil communities, since their shells are soft and less chitinized, and therefore less able to resist decomposition processes. Although fewer species were found in the sediment samples, some species were only present as remains, and thus subfossil communities contribute $20 \%$ of the local species pool. Species such as Alonella nana, Alonella quarangularis, Camptocercus rectirostris, Leydigia, Monospilus dispar and Oxyurella tenuicaudis are rarely found in active community samples, but their remains are very common in sediment samples.

To answer the question of how well the diversity of a subfossil community reflects that of the active one, the measured diversity indices of active and subfossil communities were compared. The high correlations could be explained by the great degree of similarity of the communities, corresponding to the low turnover component of ß-diversity. The cladoceran communities of the studied oxbows behaved differently in terms of the active-subfossil relationship. Those diversity metrics which depend on species richness occupy a position far from the 1:1 line (species $\alpha$-diversity metrics such as Shannon entropy, the Simpson dominance index, Hill's effective number of species, N2, and Faith's phylogenetic diversity). Those metrics that are either distance-based or tree-based measurements of diversity are close to the 1:1 line (Fig. 8), suggesting that they are useful in paleolimnological reconstruction.

The investigated the oxbows were populated by fish exercising a strong effect on cladoceran populations, and trophic status of both lakes are

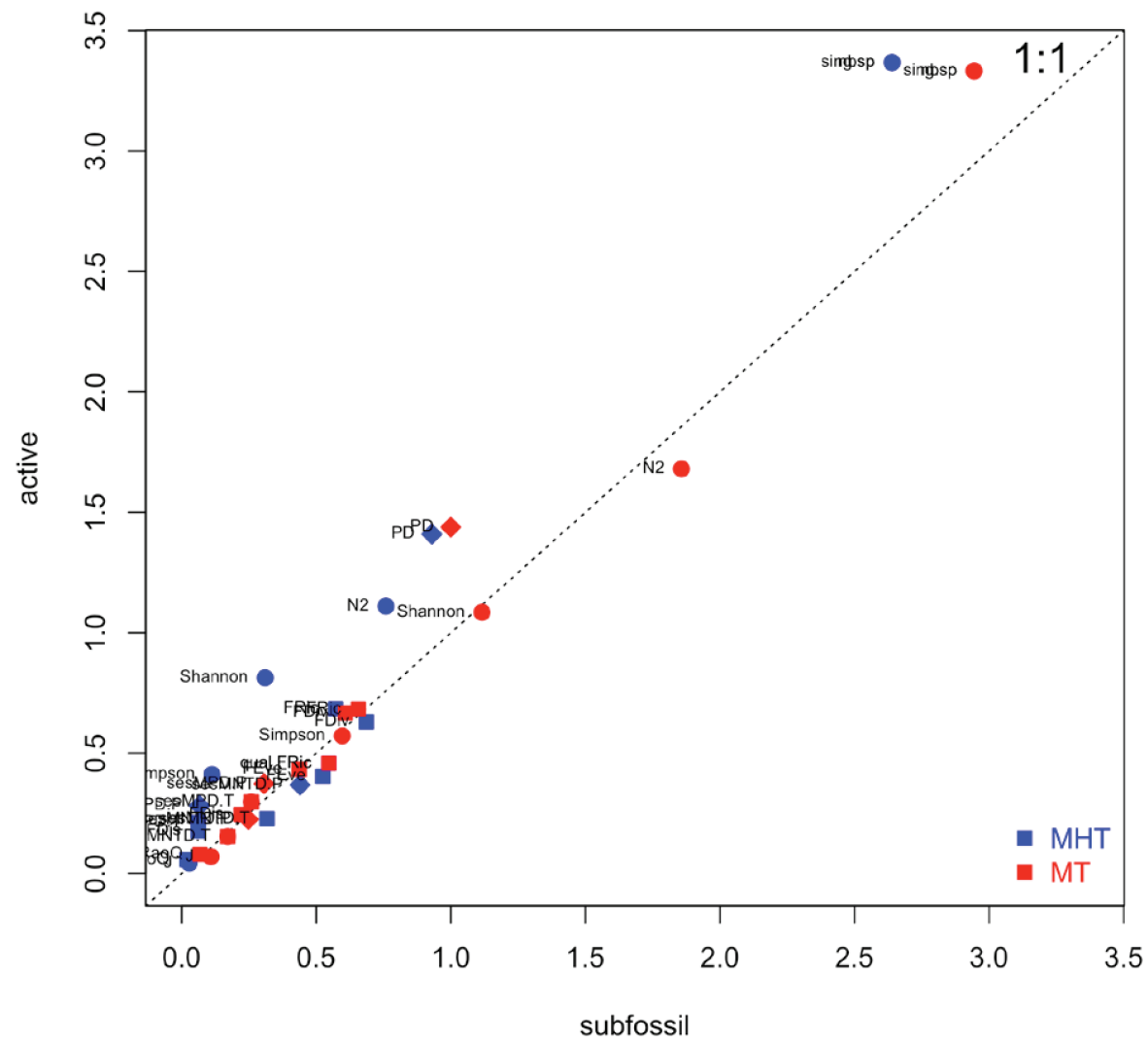

Figure 8. Scatterplot of diversity indices of active against subfossil cladoceran communities. (filled circles: species diversity indices; filled squares: functional diversity indices; diamonds: phylogenetic diversity indices). Gráfico de dispersión de los indices de diversidad de las comunidades de cladóceros activas contra las comunidades subfósiles. (círculos: índices de diversidad de especies; cuadrados: indices de diversidad funcional; rombos: índices de diversidad filogenética). 
mesotrophic, fish (top-down force) is more likely to be an environmental filter than nutrients (bottom-up force) having the effect on cladoceran communities. They differed in terms of ecosystem functioning (strength of top-down forces). The MHT is operated as fishpond, while the MT is not; the MT is almost fully covered by macrophytes, while the MHT is much less so. Diversity metrics revealed the contrast in the ecosystem functioning of the oxbows since a higher degree of diversity was measured in the MT in the case of almost all indices used in the investigation.

\section{CONCLUSIONS}

Bias between the active population of cladoceran species (source community) and the subfossil cladoceran community were investigated. Heavy chitinized species' live remains occur in the sediment, therefore biases may be found in the reconstructed communities. Biases are caused by, on the one hand, body parts of soft bodied filterers (Daphniidae, Moinidae, Sididae (Diaphanosoma $\mathrm{sp}$.)) being underrepresented in the subfossil remains of cladocerans, while on the other hand, species which are hard to collect are underrepresented or absent in contemporary samples. These latter are mostly found in littoral, are benthic or phytophylous species. Both circumstances can have a strong effect on diversity assessment. In spite of such biases, the sediment community may reflect ecosystem functioning. The subfossil cladoceran community in the MT corresponded to low fish densities and the high macrophyte coverage, representing weaker top-down forces in this oxbow. The phylogenetic and functional approach to subfossil cladocerans should prove useful in paleolimnological reconstruction, since phylogenetic and trait based diversity indices predicted properly the top-down regulation as an ecosystem function.

\section{ACKNOWLEDGEMENTS}

The research was supported by the Hungarian National Science Foundation, OTKA-T 049098; National Research, Development and Innovation Office NKFIH, 119208; Development Program BALÖKO 3B022/04, TÁMOP 4.2.2-08/1-2008-
0020, TÁMOP 4.2.1/B-09/1/KONV-2010-0006. 2007 and the European Union and the State of Hungary, co-financed by the European Regional Development Fund in the project of GINOP-2.3.2.-15-2016-00009 'ICER'. Special thanks to George Seel and Paul Thatcher for language corrections. We are very grateful for the anonymous reviewers for their advices.

\section{REFERENCES}

BABKA, B. \& S. SZABÓ. 2007. Water chemical analysis of the oxbow lakes near the Upper Tisza River. AGD Landscape \& Environment, 1 (1): 36-42.

BABKA, B., I. FUTÓ \& S. SZABÓ. 2011. Clustering oxbow lakes in the Upper-Tisza Region on the basis of stable isotope measurements. Journal of Hydrology, 410 (1-2): 105-113. DOI: 10.1016/j.jhydrol.2011.09.026

BARNETT, A. J., K. FINLAY \& B. E. BEISNER. 2007. Functional diversity of crustacean zooplankton communities: towards a trait-based classification. Freshwater Biology, 52 (5): 796-813. DOI: $10.1111 / \mathrm{j} .1365-2427$. 2007.01733.x

BASELGA, A. \& C. D. L. ORME. 2012. Betapart: An R package for the study of beta diversity. Methods in Ecology and Evolution, 3 (5): 808-812. DOI: 10.1111/j.2041-210X.2012. 00224.x

BLARQUEZ, O., C. CARCAILLET, T. FREJAVILLE \& Y. BERGERON. 2014. Disentangling the trajectories of alpha, beta and gamma plant diversity of North American boreal ecoregions since 15,500 years. Frontiers in Ecology and Evolution, 2 (April): 1-6. DOI: $10.3389 /$ fevo.2014.00006

BŁĘDZKI, L. A. \& J. I. RYBAK. 2016. Freshwater Crustacean Zooplankton of Europe: Cladocera and Copepoda (Calanoida, Cyclopoida) Key to Species Identification, with Notes on Ecology, Distribution, Methods and Introduction to Data Analysis Freshwater crustacean zooplankton of Europe.

BOERSMA, M., P. SPAAK \& L. DE MEESTER. 1998. Predator-mediated plasticity in morphology, life history, and behavior of Daphnia: the uncoupling of responses. The 
American naturalist, 152 (2): 237-48. DOI: 10.1086/286164

BORCARD, D., F. GILLET \& P. LEGENDRE. 2011. Numerical Ecology with R. R. Gentleman, K. Hornik, and G. G. Parmigiani (eds.). Springer Berlin Heidelberg.

BROOKS, J. L. \& S. I. DODSON. 1965. Predation, Body Size, and Composition of Plankton. Science, 150 (3692): 28-35. DOI: 10.1126/science. 150.3692 .28

CHRISTOFFERSEN, K., B. RIEMANN, A. KLYSNER \& M. SØNDERGAARD. 1993. Potential role of fish predation and natural populations of zooplankton in structuring a plankton community in eutrophic lake water. Limnology and Oceanography, 38 (3): 561-573. DOI: 10.4319/1o.1993.38.3.0561

CONFER, J. L. \& P. I. BLADES. 1975. Omnivorous zooplankton and planktivorous fish. Limnology and Oceanography, 20 (4): 571-579. DOI: 10.4319/1o.1975.20.4.0571

DAVIDSON, T. A., C. D. SAYER, M. R. PERROW, M. BRAMM \& E. JEPPESEN. 2007. Are the controls of species composition similar for contemporary and sub-fossil cladoceran assemblages? A study of 39 shallow lakes of contrasting trophic status. Journal of Paleolimnology, 38 (1): 117-134. DOI: 10.1007/s10933-006-9066-X

DAVIDSON, T. A., C. D. SAYER, M. PERROW, M. BRAMM \& E. JEPPESEN. 2010. The simultaneous inference of zooplanktivorous fish and macrophyte density from sub-fossil cladoceran assemblages: a multivariate regression tree approach. Freshwater Biology, 55 (3): 546-564. DOI: 10.1111/j.1365-2427.2008.02124.x

DEBASTIANI, V. J. \& L. da S. DUARTE. 2017. Evolutionary Models and Phylogenetic Signal Assessment via Mantel Test. Evolutionary Biology, 44 (1): 135-143. DOI: 10.1007/s11692-016-9396-1

DEMOTT, W. R. \& W. C. KERFOOT. 1982. Competition among cladocerans: nature of the interaction between Bosmina and Daphnia. Ecology, 63 (6): 1949-1966. DOI: $10.2307 / 1940132$

DÍAZ， S. \& M. CABIDO. 2001. Vive la différence: plant functional diversity matters to ecosystem processes. Trends in Ecology \& Evolution, 16 (11): 646-655. DOI: 10.1016/S0169-5347(01)02283-2

DODSON, S. I. 1974. Zooplankton Competition and Predation: An Experimental Test of the Size-Efficiency Hypothesis. Ecology, 55 (3): 605-613. DOI: 10.2307/1935150

DODSON, S. I. 1979. Body size patterns in arctic and temperate zooplankton. Limnology and Oceanography, 24 (5): 940-949. DOI: 10.4319/lo.1979.24.5.0940

DUMONT, H. J. 2016. Phylogenetic insights into the Anomopoda, mainly derived from a comparative study of trunk limb 1. Crustaceana, 89 (3): 307-319. DOI: 10.1163/1568540300003517

FAITH, D. P. 1992. Conservation evaluation and phylogentic diversity. Biological Conservation, 61: 1-10.

FLYNN, D. F. B., N. MIROTCHNICK, M. JAIN, M. I. PALMER \& S. NAEEM. 2011. Functional and phylogenetic diversity as predictors of biodiversity--ecosystem-function relationships. Ecology, 92 (8): 1573-1581. DOI: 10.1890/10-1245.1

FREY, D. G. 1950. The taxonomic and phylogenetic significance of the head pores of the Chydoridae (Cladocera). Internationale Revue der gesamten Hydrobiologie und Hydrographie, 44: 27-50. DOI: 10.1002/iroh. 19590440104

FREY, D. G. 1986. Cladocera analysis. In: Handbook of Holocene Palaeoecology and Palaeohydrology. B. E. Berglund (ed.): 667-692. John Wiley \& Sons.

GASTON, K. J. 2000. Global patterns in biodiversity. Nature, 405: 220-227. DOI: $10.1038 / 35012228$

GIANUCA, A. T., J. H. PANTEL \& L. DE MEESTER. 2016. Disentangling the effect of body size and phylogenetic distances on zooplankton top-down control of algae. Proceedings of the Royal Society B: Biological Sciences, 283 (1828): 20160487. DOI: 10.1098/rspb.2016.0487

GIANUCA, A. T., S. A. J. DECLERCK, M. W. CADOTTE, C. SOUFFREAU, T. DE BIE \& L. DE MEESTER. 2017. Integrating trait and phylogenetic distances to assess scale-de- 
pendent community assembly processes. Ecography, 40 (6): 742-752

GIANUCA, A. T., J. ENGELEN, K. I. BRANS, F. T. T. HANASHIRO, M. VANHAMEL, E. M. VAN DEN BERG, C. SOUFFREAU \& L. De MEESTER. 2018. Taxonomic, functional and phylogenetic metacommunity ecology of cladoceran zooplankton along urbanization gradients. Ecography, 41: 183-194. DOI: 10.1111/ecog.02926

GOULDEN, C. E. \& D. G. FREY. 1963. The Occurrence and Significance of Lateral Head Pores in the Genus Bosmina (Cladocera). Internationale Revue der gesamten Hydrobiologie und Hydrographie, 48 (3): 513-522. DOI: 10.1002/iroh.19630480304

GULYÁS, P. \& L. FORRÓ. 1999. Vol. 9 Vízi Természet- és Környezetvédelem (In Freshwater Nature Conservation and Environmental Protection) Az ágascsápú rákok (Cladocera) kishatározója (A guide for the identification of Cladocera occurring in Hungary). 2nd ed. Környezetgazdálkodási Intézet, Budapest.

HAMILTON, A. J. 2005. Species diversity or biodiversity? Journal of Environmental Management, 75 (1): 89-92. DOI: 10.1016/j. jenvman.2004.11.012

HILL, M. O. 1973. Diversity and Evenness?: A Unifying Notation and Its Consequences. Ecology, 54 (2): 427-432. DOI: 10.2307/1934352

HOFMANN, W. 1983. Stratigraphy of Cladocera and Chironomidae in a core from a shallow North German lake. Hydrobiologia, 103 (1): 235-239. DOI: 10.1007/BF00028458

IGLESIAS, C., N. MAZZEO, M. MEERHOFF, G. LACEROT, J. M. CLEMENTE, F. SCASSO, C. KRUK, G. GOYENOLA, J. GARCÍA-ALONSO, S. L. AMSINCK, J. C. PAGGI, S. J. de PAGGI \& E. JEPPESEN. 2011. High predation is of key importance for dominance of small- bodied zooplankton in warm shallow lakes: evidence from lakes, fish exclosures and surface sediments. Hydrobiologia, 667: 133-147. DOI: 10.1007/s10750-011-0645-0

JEPPESEN, E., J. P. JENSEN, M. SØNDERGAARD, T. LAURIDSEN, L. J. PEDERSEN \& L. JENSEN. 1997. Top-down control in freshwater lakes?: the role of nutrient state , submerged macrophytes and water depth A. P. J. I. R. L Kufel (ed.). Hydrobiologia, 342 (1761): 151-164. DOI: 10.1023/a:1017046130329

JEPPESEN, E., J. P. JENSEN, M. SØNDERGAARD \& T. LAURIDSEN. 2000. Trophic structure, species richness and biodiversity in Danish lakes: changes along a phosphorus gradient. Freshwater Biology, 45: 201-218. DOI: $10.1046 / j .1365-2427.2000 .00675 . x$

JEPPESEN, E., M. SØNDERGAARD, M. SØNDERGAARD, J. THEIL-NIELSEN \& $\mathrm{K}$. JÜRGENS. 2002. Cascading trophic interactions in the littoral zone: an enclosure experiment in shallow Lake Stigsholm, Denmark. Fundamental and Applied Limnology, 153 (4): 533-555. DOI: $10.1127 /$ archiv-hydrobiol/ $153 / 2002 / 533$

JEPPESEN, E., M. MEERHOFF, B. A. JACOBSEN, R. S. HANSEN, M. SØNDERGAARD, J. P. JENSEN, T. L. LAURIDSEN, N. MAZZEO \& C. W. C. BRANCO. 2007. Restoration of shallow lakes by nutrient control and biomanipulation - the successful strategy varies with lake size and climate. Hydrobiologia, 581 (1): 269-285. DOI: 10.1007/s10750-006-0507-3

JEPPESEN, E., P. NÕGES, T. A. DAVIDSON, J. HABERMAN, T. NÕGES, K. BLANK, T. L. LAURIDSEN, M. SØNDERGAARD, C. SAYER, R. LAUGASTE, L. S. JOHANSSON, R. BJERRING \& S. L. AMSINCK. 2011. Zooplankton as indicators in lakes: a scientific-based plea for including zooplankton in the ecological quality assessment of lakes according to the European Water Framework Directive (WFD). Hydrobiologia, 676 (1): 279-297. DOI: 10.1007/s10750-0110831-0

JEPPESEN, E., M. SØNDERGAARD, T. L. LAURIDSEN, T. A. DAVIDSON, Z. LIU, N. MAZZEO, C. TROCHINE, K. ÖZKAN, H. S. JENSEN, D. TROLLE, F. STARLING, X. LAZZARO, L. S. JOHANSSON, R. BJERRING, L. LIBORIUSSEN, S. E. LARSEN, F. LANDKILDEHUS, S. EGEMOSE \& $\mathrm{M}$. MEERHOFF. 2012. Biomanipulation as a Restoration Tool to Combat Eutrophication: Recent Advances and Future Challenges. In: Global Change in Multispecies Systems Part 
2. Advances in Ecological Research. G. Woodward, U. Jacob, and E. J. O'Gorman (eds.): 411-488. Academic Press.

JOST, L. 2006. Entropy and diversity. Oikos, 113: 363-375. DOI: 10.1111/j.2006.00301299.14714.x

JOST, L. 2007. Partitioning diversity into independent alpha and beta components. Ecology, 88 (10): 2427-2439. DOI: 10.1890/07-1861.1

KAPPES, H. \& U. SINSCH 2002. Temperatureand predator-induced phenotypic plasticity in Bosmina cornuta and B. pellucida (Crustacea: Cladocera). Freshwater Biology, 47: 1944-1955. DOI: 10.1046/j.1365-2427.2002. 00943.x

KATTEL, G. R., R. W. BATTARBEE, A. MACKAY \& H. J. B. BIRKS. 2007. Are cladoceran fossils in lake sediment samples a biased reflection of the communities from which they are derived? Journal of Paleolimnology, 38 (2): 157-181. DOI: 10.1007/ s10933-006-9073-y

KEARNS, C. M. 1996. Particle transport by benthic invertebrates: Its role in egg bank dynamics. Hydrobiologia, 332 (1): 63-70. DOI: $10.1007 / \mathrm{BF} 00020780$

KEMBEL, S. W., P. D. COWAN, M. R. HELMUS, W. K. CORNWELL, H. MORLON, D. D. ACKERLY, S. P. BLOMBERG \& C. O. WEBB. 2010. Picante: R tools for integrating phylogenies and ecology. Bioinformatics, 26 (11): 1463-1464. DOI: 10.1093/bioinformatics/btq166

KERFOOT, W. C. \& L. J. WEIDER. 2004. Experimental paleoecology (resurrection ecology): Chasing Van Valen's Red Queen hypothesis. Limnology and Oceanography, 49 (4_part_2): 1300-1316. DOI: 10.4319/1o.2004. 49.4_part 2.1300

KORHOLA, A. \& M. RAUTIO 2001. 2. Cladocera and other Branchiopod crustaceans. In: Tracking Environmental Change Using Lake Sediments. Volume 4: Zoological Indicators. J. P. Smol, H. J. B. Birks, and W. M. Last (eds.): 5-41. Kluwer Academic Publishers, Dordrecht, The Netherlands.

KORPONAI, J., I. GYULAI, M. BRAUN, C. KÖVÉR, I. PAPP \& L. FORRÓ. 2016. Reconstruction of flood events in an oxbow lake
(Marótzugi-Holt-Tisza, NE Hungary) by using subfossil cladocerans remains and sediments. Advances in Oceanography and Limnology, 7 (2): 125-135. DOI: 10.4081/aiol.2016.6168

LAFORSCH, C. \& R. TOLLRIAN. 2004. Inducible defenses in multipredator environments: cyclomorphosis in Daphnia cucullata. Ecology, 85 (8): 2302-2311. DOI: 10.1890/03-0286 LALIBERTÉ, E. \& P. LEGENDRE. 2010. A distance-based framework for measuring functional diversity from multiple traits A distance-based framework for measuring from multiple traits functional diversity. Ecology, 91 (1): 299-305. DOI: 10.1890/08-2244.1

LALIBERTÉ, E., P. LEGENDRE \& B. SHIPLEY. 2014. FD: measuring functional diversity from multiple traits, and other tools for functional ecology. $R$ package version 1.0-12. http://cran.r-project.org/web/packages/ FD/FD.pdf

LÁSZLÓFFY, W. 1982. The River Tisza. Akadémiai Kiadó. Budapest.

LAURIDSEN, T. L., J. P. JENSEN, E. JEPPESEN \& M. SØNDERGAARD. 2003. Response of submerged macrophytes in Danish lakes to nutrient loading reductions and biomanipulation. Hydrobiologia, 506-509: 641-649. DOI: 10.1023/B:HYDR. 0000008633.17385.70

LITCHMAN, E., M. D. OHMAN \& T. KIØRBOE. 2013. Trait-based approaches to zooplankton communities. Journal of Plankton Research, 35 (3): 473-484. DOI: 10.1093/plankt/fbt019

MASON, N. W. H., D. MOUILLOT, W. G. LEE \& J. B. WILSON. 2005. Functional richness, functional and functional evenness divergence: the primary of functional components diversity. Oikos, 111 (1): 112-118. DOI: 10.1111/j.0030-1299.2005.13886.x

NEVALAINEN, L. 2011. Intra-lake heterogeneity of sedimentary cladoceran (Crustacea) assemblages forced by local hydrology. Hydrobiologia, 676 (1): 9-22. DOI: 10.1007/s10750-011-0707-3

NEVALAINEN, L., M. V. RANTALA \& T. P. LUOTO. 2015. Sedimentary cladoceran assemblages and their functional attributes record late Holocene climate variability in 
southern Finland. Journal of Paleolimnology: 1-14. DOI: 10.1007/s10933-015-9849-z

NEVALAINEN, L. \& T. P. LUOTO. 2017. Relationship between cladoceran (Crustacea) functional diversity and lake trophic gradients. Functional Ecology, 31 (2): 488-498. DOI: $10.1111 / 1365-2435.12737$

NEVALAINEN, L., M. BROWN \& M. MANCA. 2018. Sedimentary Record of Cladoceran Functionality under Eutrophication and Re-Oligotrophication in Lake Maggiore, Northern Italy. Water (Switzerland) 10: 86. DOI: $10.3390 / \mathrm{w} 10010086$

NYKÄNEN, M., K. VAKKILAINEN, M. LIUKKONEN \& T. KAIRESALO. 2009. Cladoceran remains in lake sediments: a comparison between plankton counts and sediment records. Journal of Paleolimnology, 42 (4): 551-570. DOI: 10.1007/s10933-008-9304-5

NYKÄNEN, M., T. MALINEN, K. VAKKILAINEN, M. LIUKKONEN \& T. KAIRESALO. 2010. Cladoceran community responses to biomanipulation and re-oligotrophication in Lake Vesijärvi, Finland, as inferred from remains in annually laminated sediment. Freshwater Biology, 55 (6): 1164-1181. DOI: 10.1111/j.1365-2427.2009.02341.x

OKSANEN, J., F. G. BLANCHET, M. FRIENDLY, R. KINDT, P. LEGENDRE, D. MCGLINN, P. R. MINCHIN, R. B. O'HARA, G. L. SIMPSON, P. SOLYMOS, M. H. H. STEVENS, E. SZOECS \& H. WAGNER. 2017. vegan: Community Ecology Package. R package ver. 2.4-5: 254. DOI: 10.4135/9781412971874.n145

PÁLFAI, I. ed. 2003. Oxbow-lakes in Hungary. Ministry of Environmental Control and Water Management. Budapest.

PODANI, J. 1999. Extending Gower's general coefficient of similarity to ordinal characters. Taxon, 48 (2): 331-340. DOI: 10.2307/1224438

POMERLEAU, C., A. R. SASTRI \& B. E. BEISNER. 2015. Evaluation of functional trait diversity for marine zooplankton communities in the Northeast subarctic Pacific Ocean. Journal of Plankton Research, 37: 712-726. DOI: $10.1093 /$ plankt/fbv045

R CORE TEAM 2017. R: A language and environment for statistical computing. $R$ Founda- tion for Statistical Computing, Vienna, Austria. URL http://www.R-project.org.

RHODE, S. C., M. PAWLOWSKI \& R. TOLLRIAN. 2001. The impact of ultraviolet radiation on the vertical distribution of zooplankton of the genus Daphnia. Nature, 412 (6842): 69-72. DOI: $10.1038 / 35083567$

RIZO, E. Z. C., Y. GU, R. D. S. PAPA, H. J. DUMONT \& B. P. HAN. 2017. Identifying functional groups and ecological roles of tropical and subtropical freshwater Cladocera in Asia. Hydrobiologia, 799 (1): 83-99. DOI: 10.1007/s10750-017-3199-y

SAKAMOTO, M. \& T. HANAZATO. 2008. Antennule shape and body size of Bosmina: key factors determining its vulnerability to predacious Copepoda. Limnology, 9 (1): 27-34. DOI: 10.1007/s10201-007-0231-3

SAYER, C. D., A. BURGESS, K. KARI, T. A. DAVIDSON, S. PEGLAR, H. YANG \& N. ROSE. 2010. Long-term dynamics of submerged macrophytes and algae in a small and shallow, eutrophic lake: implications for the stability of macrophyte-dominance. Freshwater Biology, 55 (3): 565-583. DOI: 10.1111/j.1365-2427.2009.02353.x

SCHEFFER, M. 2001. Alternative attractors of shallow lakes. The Scientific World Journal, 1: 254-63. DOI: $10.1100 /$ tsw.2001.62

SCHLEUTER, D., M. DAUFRESNE, F. MASSOL \& C. ARGILLIER. 2010. A user' $\mathrm{s}$ guide to functional diversity indices. Ecological Monographs, 80 (3): 469-484. DOI: 10.1890/08-2225.1

SMIRNOV, N. N. 2017. Physiology of the Cladocera. 2nd ed. Academic Press, London.

SMOL, J. P. 2002. Pollution of Lakes and Rivers. Blackwell Publishing. Oxford.

SOMMERWERK, N., T. HEIN, M. SCHNEIDER-JACOBY, C. BAUMGARTNER, A. OSTOJIC, R. SIBER, J. BLOESCH, M. PAUNOVIC \& K. TOCKNER. 2009. Chapter 3 The Danube River Basin. In: Rivers of Europe. $\mathrm{K}$. Tockner, U. Uehlinger, and C. T. Robinson (eds.): 59-112. Academic Press. London.

SPAAK, P. 1997. Tail spine length in the Daphnia galeata complex: costs and benefits of induction by fish. Aquatic Ecology, 31: 89-98. DOI: 10.1023/A:1009935100804. 
SWENSON, N. G. 2014. Functional and Phylogenetic Ecology in R. Springer New York. New York, NY. DOI: 10.1007/978-1-4614-9542-0

SZABÓ, J., R. VASS \& C. TÓTH. 2012. Examination of fluvial development on study areas of Upper-Tisza region. Carpathian Journal of Earth and Environmental Sciences, 7 (4): 241-253.

SZEROCZYNSKA, K. \& K. SARMAJA-KORJONEN. 2007. Atlas of subfossil Cladocera from Central and Northern Europe. Friends of Lower Vistula Society. Swiecie.

TELFORD, R. J. \& H. J. B. BIRKS. 2011. A novel method for assessing the statistical significance of quantitative reconstructions inferred from biotic assemblages. Quaternary Science Reviews, 30 (9-10): 1272-1278. DOI: 10.1016/j.quascirev.2011.03.002

THOMPSON, P. L., T. J. DAVIES \& A. GONZALEZ. 2015. Ecosystem functions across trophic levels are linked to functional and phylogenetic diversity. PloS one, 10 (2): e0117595. DOI: 10.1371/journal.pone.0117595

VIJVERBERG, J. \& M. BOERSMA. 1997. Long-term dynamics of small-bodied and large-bodied cladocerans during the eutrophication of a shallow reservoir, with special attention for Chydorus sphaericus. Hydrobiologia, 360: 233-242. DOI:
10.1023/A:1003148600983

WALKER, B. H. 1992. Biodiversity and Ecological Redundancy. Conservation Biology, 6 (1): 18-23. DOI: 10.1046/j.1523-1739.1992. 610018.x

WEBB, C. O., D. D. ACKERLY, M. A. MCPEEK \& M. J. DONOGHUE. 2002. Phylogenies and Community Ecology. Annual Review of Ecology and Systematics, 33: 475-505. DOI: 10.1146/annurev.ecolsys. 33.010802.15044

WEBB, C. O., D. D. ACKERLY \& S. W. KEMBEL. 2008. Phylocom: Software for the analysis of phylogenetic community structure and trait evolution. Bioinformatics, 24 (18): 2098-2100. DOI: 10.1093/bioinformatics/ btn358

WHITTAKER, R. H. 1972. Evolution and Measurement of Species Diversity. Taxon, 21 (2/3): 213. DOI: $10.2307 / 1218190$

ZARET, T. M. \& W. C. KERFOOT. 1975. Fish Predation on Bosmina longirostris: Body-Size Selection Versus Visibility Selection. Ecology, 56 (1): 232-237. DOI: 10.2307/1935317

ZHURAVLEV, A. Y.\& E. B. NAIMARK. 2005. Alpha, beta, or gamma: Numerical view on the Early Cambrian world. Palaeogeography, Palaeoclimatology, Palaeoecology, 220 (1-2): 207-225. DOI: 10.1016/j.palaeo.2004.08.009

Con el apoyo de:

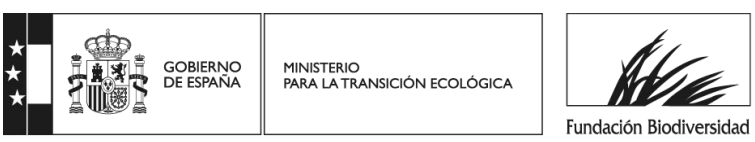

